\title{
Meta-analysis of the effects of soil properties, site factors and experimental conditions on solute transport
}

\author{
J. K. Koestel, J. Moeys, and N. J. Jarvis \\ Department of Soil and Environment, Swedish University of Agricultural Sciences (SLU), P.O. Box 7014, \\ 75007 Uppsala, Sweden
}

Correspondence to: J. K. Koestel (john.koestel@ slu.se)

Received: 27 October 2011 - Published in Hydrol. Earth Syst. Sci. Discuss.: 15 November 2011

Revised: 21 May 2012 - Accepted: 22 May 2012 - Published: 13 June 2012

\begin{abstract}
Preferential flow is a widespread phenomenon that is known to strongly affect solute transport in soil, but our understanding and knowledge is still poor of the site factors and soil properties that promote it. To investigate these relationships, we assembled a database from the peer-reviewed literature containing information on 733 breakthrough curve experiments under steady-state flow conditions. Most of the collected experiments (585 of the 733 datasets) had been conducted on undisturbed soil columns, although some experiments on repacked soil, clean sands, and glass beads were also included. In addition to the apparent dispersivity, we focused our attention on three indicators of preferential solute transport: namely the 5\%-arrival time, the holdback factor, and the ratio of piston-flow and average transport velocities. Our results suggest that, in contrast to the $5 \%$-arrival time and the holdback factor, the piston-flow to transport velocity ratio is not related to preferential macropore transport but rather to the exclusion or retardation of the applied tracer. Confirming that the apparent longitudinal dispersivity is positively correlated with the travel distance of the tracer, our results also illustrate that this relationship is refined if the normalized $5 \%$-tracer arrival time is also taken into account. In particular, we found that the degree of preferential solute transport increases with apparent dispersivity and decreases with travel distance. A similar but weaker relationship was observed between apparent dispersivity, $5 \%$-tracer arrival time, and lateral observation scale, such that the degree of preferential transport increases with lateral observation scale. However, we also found that the travel distance and the lateral observation scale in the investigated dataset are correlated, which makes it difficult to distinguish their influence on these transport characteristics. We also found that
\end{abstract}

the strength of preferential transport increased at larger flow rates and water saturations, which suggests that macropore flow was a more important flow mechanism than heterogeneous flow in the soil matrix. Nevertheless, our data show that heterogeneous flow in the soil matrix also occasionally leads to strong preferential transport. Furthermore, we show that preferential solute transport under steady-state flow depends on soil texture in a threshold-like manner: moderate to strong preferential transport was found to occur only for undisturbed soils that contain more than $8 \%$ clay. Preferential flow characteristics were also absent for columns filled with glass beads, clean sands, or sieved soil. No clear effect of land use on the pattern of solute transport could be discerned, probably because the available dataset was too small and too strongly affected by cross-correlations with experimental conditions. Our results suggest that, in developing pedotransfer functions for solute transport properties of soils, it is critically important to account for travel distance, lateral observation scale, and water flow rate and saturation.

\section{Introduction}

During recent decades the number and quantity of man-made substances that are released onto the soil has been increasing exponentially. Therefore, it is becoming more and more important to be able to quantify and predict water and solute fluxes through soil, as knowledge of the latter is fundamental to deciding on appropriate prevention or remediation strategies. Quantitatively accurate estimation of water and solute fluxes in soils requires knowledge of hydraulic and solute transport properties. However, their direct measurement 
is labour-intensive and costly and is only feasible for small soil samples. As soil hydraulic and transport properties are in most cases spatially highly variable, it is not possible to measure them directly at the relevant scales for management, such as the field, region or landscape scale. Although they do not solve the scale issues, pedotransfer functions (PTFs) offer an inexpensive way to replace direct measurements (Wösten et al., 2001). PTFs denote an approach in which soil properties that are difficult to measure, e.g. the water retention properties, are estimated using other soil properties that are easier to measure, e.g. the bulk density or texture, as proxy variables. Most work so far has focused on soil hydraulic properties, and very little effort has been devoted to developing PTFs for solute transport characteristics. Some approaches for identifying "local" PTFs for parameters of the convection-dispersion equation (CDE) or the mobileimmobile model (MIM) have been published based on relatively small datasets (less than 25 samples in all cases) that had been collected explicitly for the purpose (e.g. Goncalves et al., 2001; Perfect et al., 2002; Shaw et al., 2000; Vervoort et al., 1999). In other studies, data from peer-reviewed literature were assembled to construct larger databases of solute breakthrough curve (BTC) experiments (e.g. Rose, 1977; Beven et al., 1993; Griffioen et al., 1998; Oliver and Smettem, 2003). In these studies, the authors investigated correlations among CDE and MIM model parameters of between 50 and 359 BTC experiments, but links to soil properties and experimental conditions were hardly discussed. In contrast, such links were explicitly established in the study by Bromly et al. (2007), who focused on the relationship of a CDE model parameter, the (longitudinal) dispersivity, to properties of saturated repacked soil columns. Their database comprised 291 entries. Another large database of BTC data was published by Vanderborght and Vereecken (2007). It contains 635 datasets of flux and resident concentration BTC experiments with conservative tracers on undisturbed soil and covers all scales between the small column-scale and the fieldscale. Vanderborght and Vereecken (2007) used the dataset to investigate how the longitudinal dispersivity is related to scale, boundary conditions, soil texture, and measurement method. They confirmed that the transport distance and the longitudinal dispersivity are generally positively correlated in soils. The same observation had been previously reported for tracer experiments in groundwater (Gelhar et al., 1992; Neuman, 1990).

All of the above discussed studies have "a priori" assumed the validity of one solute transport model, usually the CDE or the MIM. However, it seems likely that no single model is able to properly characterize all of the contrasting flow regimes found in soils, including convective-dispersive transport, heterogeneous flow (funnel flow), non-equilibrium flow in soil macropores or unstable finger flow (Jury and Flühler, 1992). Indeed, it is commonly found that the flow or mixing regime may change one or more times along the travel path (e.g. Vanderborght et al., 2001), as soils are predominantly layered in the horizontal direction and solute transport normally takes place in the vertical direction. Vanderborght et al. (2001) also found that the mixing regime in one and the same soil depends on the applied water flow conditions.

In effect, a simple generally applicable model for solute transport in soils, which is at the same time consistent with the underlying physics, is presently not available for scales larger than the pore-scale. Therefore, model-independent (non-parametric) PTFs for solute transport properties should be preferred to model-dependent ones. Some indicator of the strength of preferential transport is then required in place of the model parameters. Several candidates for such an indicator have been proposed during recent years. Among them are the skewness of the BTC (e.g. Stagnitti et al., 2000), the pore volumes drained at the arrival of the peak concentration (Ren et al., 1996; Comegna et al., 1999), the "holdback factor", defined as the amount of original water remaining in a column when one pore volume of displacing water has entered (Danckwerts, 1953; Rose, 1973), and early quantiles of solute arrival times (Knudby and Carrera, 2005).

In this study, we expand and broaden earlier efforts (e.g. Vanderborght and Vereecken, 2007) to develop a database of solute transport experiments derived from the published literature, which comprises a larger number of BTCs $(n=733)$ with accompanying information on soil properties, site factors (e.g. land use and soil management) and experimental conditions. In contrast to Vanderborght and Vereecken (2007), we only included BTC experiments with direct flux concentration measurements to improve comparability of the collected data. Our main motivation for this work was to create a dataset of transport experiments to enable the future development of non-parametric PTFs for inert solute transport. In this paper, we present the database and the results of initial analyses that relate derived BTC-shape measures to experimental boundary conditions, soil properties and site factors.

\section{Material and methods}

We collected information on 733 BTCs for inert tracers in steady-state flow experiments on undisturbed soil samples and from a smaller number of columns filled with glass beads, clean sands, or sieved and repacked soil. The data were taken from 76 articles published in the peer-reviewed literature. Details on the data sources are given in Table 1. We deliberately excluded BTCs consisting of resident concentration data (e.g. sampled by time-domain reflectometry) or data from local sampling methods (e.g. suction samplers). Thus, all the considered BTCs were obtained from measurements of flux concentrations in column effluents. Alongside the BTCs, additional information on corresponding soil properties, site factors and experimental conditions was gathered and stored in a relational MySQL database. Table 2 gives an overview on soil properties, site factors and experimental 
Table 1. Primary source publication and other information on the BTC experiments collected in the meta-database.

\begin{tabular}{|c|c|c|c|c|c|c|c|c|}
\hline primary reference & \# of BTCs & tracer & $\begin{array}{l}\text { PDF estimated } \\
\text { from }\end{array}$ & median $R^{2}$ & $\begin{array}{l}\text { type of soil or } \\
\text { porous medium }\end{array}$ & $\begin{array}{l}\text { USDA texture } \\
\text { class }\end{array}$ & $\begin{array}{l}\text { undist. } \\
\text { sample? }\end{array}$ & land use \\
\hline Akhtar et al. (2003) & 9 & chloride & $\begin{array}{l}\text { MIM and } \\
\text { CDE param. }\end{array}$ & 0.98 & $\begin{array}{l}\text { lamellic } \\
\text { hapludalf**, } \\
\text { glossaquic } \\
\text { hapludalf**, } \\
\text { fluventic } \\
\text { eutrudept**, } \\
\text { glossic hapludalf**, } \\
\text { typic fragiudept** }\end{array}$ & $\begin{array}{l}\text { loamy sand, } \\
\text { loam, } \\
\text { silt loam }\end{array}$ & yes & unknown \\
\hline Anamosa et al. (1990) & 6 & tritium & MIM param. & unknown & $\begin{array}{l}\text { typic } \\
\text { gibbsiorthox** }\end{array}$ & unknown & yes & arable \\
\hline Bedmar et al. (2008) & 6 & bromide & MIM param. & 0.97 & unknown & $\begin{array}{l}\text { silt loam, } \\
\text { silty clay loam }\end{array}$ & yes & arable \\
\hline Bromly and Hinz (2004) & 14 & $\begin{array}{l}\text { lissamine } \\
\text { FF }\end{array}$ & MIM param. & unknown & clean sand & sand & no & irrelevant \\
\hline Candela et al. (2007) & 7 & bromide & CDE param. & unknown & typic xerorthents** & silt loam & no & unknown \\
\hline Coats and Smith (1964) & 2 & calcium & MIM param. & unknown & alundum & unknown & no & irrelevant \\
\hline Comegna et al. (1999) & 3 & chloride & $\begin{array}{l}\text { CDE param. } \\
\text { and raw data }\end{array}$ & unknown & $\begin{array}{l}\text { entisol }^{*}, \\
\text { vertisol }^{*} \\
\text { andosol }^{*}\end{array}$ & $\begin{array}{l}\text { sand, } \\
\text { clay loam, } \\
\text { sandy loam }\end{array}$ & yes & arable \\
\hline Comegna et al. (2001) & 17 & chloride & CDE param. & 0.996 & $\begin{array}{l}\text { orchard, } \\
\text { arable }\end{array}$ & $\begin{array}{l}\text { silt loam, } \\
\text { silty clay loam }\end{array}$ & yes & unknown \\
\hline de Smedt and Wierenga (1984) & 13 & chloride & $\begin{array}{l}\text { MIM and } \\
\text { CDE param. }\end{array}$ & unknown & glass beads & sand & no & irrelevant \\
\hline Dousset et al. (2004) & 6 & bromide & raw data & 0.99 & gleyic luvisol* & silty clay loam & $\begin{array}{l}\text { yes, } \\
\text { no }\end{array}$ & grass ley \\
\hline Dufey et al. (1982) & 10 & chloride & CDE param. & unknown & unknown & sandy loam & no & unknown \\
\hline Dyson and White (1987) & 1 & chloride & raw data & 0.999 & calcaric cambisol $^{*}$ & sandy clay loam & yes & $\begin{array}{l}\text { managed } \\
\text { grassland }\end{array}$ \\
\hline Dyson and White (1989) & 17 & chloride & raw data & 0.999 & calcaric cambisol* & sandy clay loam & yes & $\begin{array}{l}\text { managed } \\
\text { grassland }\end{array}$ \\
\hline Elrick and French (1966) & 2 & chloride & CDE param. & unknown & unknown & $\begin{array}{l}\text { loam, } \\
\text { silt loam }\end{array}$ & yes, no & unknown \\
\hline Ersahin et al. (2002) & 12 & bromide & MIM param. & 0.988 & mollic planosol ${ }^{*}$ & silt loam & yes & $\begin{array}{l}\text { natural } \\
\text { grassland }\end{array}$ \\
\hline Gaber et al. (1995) & 4 & tritium & MIM param. & 0.98 & typic haploboroll** & silty clay loam & yes & unknown \\
\hline Garré et al. (2010) & 2 & chloride & raw data & 0.996 & orthic luvisol* & silt loam & yes & arable \\
\hline Gaston et al. (2007) & 4 & bromide & MIM param. & unknown & $\begin{array}{l}\text { thermic } \\
\text { ochraqualf** }^{* *}\end{array}$ & clay loam & yes & arable \\
\hline Gaston and Locke (1996) & 4 & bromide & MIM param. & unknown & $\begin{array}{l}\text { thermic } \\
\text { ochraqualf** }^{* *}\end{array}$ & clay loam & yes & arable \\
\hline Gaston and Locke (2000) & 4 & bromide & MIM param. & unknown & $\begin{array}{l}\text { thermic } \\
\text { ochraqualf** }^{* *}\end{array}$ & clay loam & yes & arable \\
\hline Goncalves et al. (2001) & 16 & chloride & MIM param. & 0.992 & $\begin{array}{l}\text { dystric fluvisol*, } \\
\text { calcic vertisol*, }^{*} \\
\text { calcaric cambisol* }^{*} \text {, } \\
\text { vertic luvisol* }\end{array}$ & $\begin{array}{l}\text { loam, } \\
\text { clay, } \\
\text { clay loam, } \\
\text { sandy clay } \\
\text { loam, } \\
\text { sandy loam, } \\
\text { sandy clay }\end{array}$ & yes & $\begin{array}{l}\text { arable, } \\
\text { orchard }\end{array}$ \\
\hline Gwo et al. (1995) & 3 & bromide & $\begin{array}{l}\text { MIM and } \\
\text { CDE param. }\end{array}$ & unknown & unknown & unknown & yes & forest \\
\hline Haws et al. (2004) & 5 & bromide & raw data & 0.999 & $\begin{array}{l}\text { mesic typic } \\
\text { endoquoll }^{* *}\end{array}$ & silt loam & yes & arable \\
\hline Helmke et al. (2005) & 24 & $\begin{array}{l}\text { bromide } \\
\text { PFBA, } \\
\text { PIPES }\end{array}$ & $\begin{array}{l}\text { MIM and } \\
\text { CDE param. }\end{array}$ & unknown & $\begin{array}{l}\text { typic hapludoll**, } \\
\text { typic hapludalf** }\end{array}$ & $\begin{array}{l}\text { loam, } \\
\text { clay loam, } \\
\text { sandy loam }\end{array}$ & yes & irrelevant \\
\hline
\end{tabular}


Table 1. Continued.

\begin{tabular}{|c|c|c|c|c|c|c|c|c|}
\hline Jacobsen et al. (1992) & 10 & $\begin{array}{l}\text { tritium, } \\
\text { chloride }\end{array}$ & MIM param. & 0.99 & $\begin{array}{l}\text { orthic } \\
\text { haplohumod }^{* *}\end{array}$ & loamy sand & yes & unknown \\
\hline Javaux and Vanclooster (2003) & 9 & chloride & CDE param. & unknown & $\begin{array}{l}\text { unconsolidated } \\
\text { bedrock }\end{array}$ & sand & yes & irrelevant \\
\hline Jensen et al. (1996) & 19 & chloride & MIM param. & 0.998 & unknown & sandy loam & yes & arable \\
\hline Jensen et al. (1998) & 2 & tritium & raw data & 0.995 & aeric glossaqualf** & sandy loam & yes & arable \\
\hline Jorgensen et al. (2004) & 4 & bromide & MIM param. & unknown & unknown & $\begin{array}{l}\text { sandy loam, } \\
\text { sandy clay loam }\end{array}$ & yes & arable \\
\hline Kamra et al. (2001) & 45 & bromide & $\begin{array}{l}\text { MIM and } \\
\text { CDE param. }\end{array}$ & unknown & unknown & sandy loam, & yes & $\begin{array}{l}\text { arable, } \\
\text { forest }\end{array}$ \\
\hline Kasteel et al. (2000) & 1 & bromide & MIM param. & unknown & orthic luvisol* & silt loam & yes & arable \\
\hline Kim et al. (2007) & 7 & bromide & $\begin{array}{l}\text { MIM and } \\
\text { CDE param. }\end{array}$ & 0.999 & unknown & unknown & no & unknown \\
\hline Kjaergaard et al. (2004) & 33 & tritium & raw data & 0.992 & stagnic luvisol* & $\begin{array}{l}\text { sandy loam, } \\
\text { sandy clay } \\
\text { loam, } \\
\text { clay }\end{array}$ & yes & arable \\
\hline Koestel et al. (2009a) & 4 & chloride & CDE param. & 0.99 & gleyic cambisol* & loamy sand & yes & arable \\
\hline Krupp and Elrick (1968) & 5 & chloride & $\begin{array}{l}\text { MIM and } \\
\text { CDE param. }\end{array}$ & unknown & glass beads & sand & no & irrelevant \\
\hline Langner et al. (1999) & 18 & PFBA & $\begin{array}{l}\text { MIM and } \\
\text { CDE param. }\end{array}$ & 0.988 & typic haploboroll** & unknown & yes & $\begin{array}{l}\text { managed } \\
\text { grassland }\end{array}$ \\
\hline Lee et al. (2000) & 3 & chloride & MIM param. & 0.999 & stagnosol* & unknown & yes & arable \\
\hline Lee et al. (2001) & 4 & bromide & raw data & 0.998 & stagnosol* & loam & yes & arable \\
\hline Lennartz et al. (2008) & 3 & bromide & raw data & 0.972 & rendzik leptosol* & silt loam & yes & arable \\
\hline Luo et al. (2010) & 8 & bromide & raw data & 0.998 & $\begin{array}{l}\text { mesic typic } \\
\text { hapludalf** }\end{array}$ & silt loam & yes & $\begin{array}{l}\text { arable, } \\
\text { managed } \\
\text { grassland }\end{array}$ \\
\hline Maraqa et al. (1997) & 33 & tritium & $\begin{array}{l}\text { MIM and } \\
\text { CDE param. }\end{array}$ & unknown & $\begin{array}{l}\text { typic } \\
\text { udipsamment**, } \\
\text { entic haplaquod** }\end{array}$ & sand & no & unknown \\
\hline Mayes et al. (2003) & 28 & $\begin{array}{l}\text { bromide } \\
\text { PFBA, } \\
\text { PIPES }\end{array}$ & $\begin{array}{l}\text { MIM and } \\
\text { CDE param. }\end{array}$ & 0.97 & $\begin{array}{l}\text { acidic Inceptisol**, } \\
\text { unconsolidated } \\
\text { bedrock }\end{array}$ & $\begin{array}{l}\text { silt loam, } \\
\text { sandy loam }\end{array}$ & yes & $\begin{array}{l}\text { unknown, } \\
\text { forest }\end{array}$ \\
\hline McIntosh et al. (1999) & 4 & $\begin{array}{l}\text { bromide, } \\
\text { chloride }\end{array}$ & raw data & 0.993 & $\begin{array}{l}\text { thermic typic } \\
\text { dystrochrept }^{* *} \text {, } \\
\text { thermic } \\
\text { kanhapludult }^{* *}\end{array}$ & $\begin{array}{l}\text { sandy clay loam } \\
\text { sandy loam }\end{array}$ & yes & forest \\
\hline Montoya et al. (2006) & 23 & bromide & raw data & 0.992 & typic argiudoll ${ }^{* *}$ & clay loam, loam & yes & arable \\
\hline Mooney and Morris (2008) & 3 & chloride & raw data & 0.989 & $\begin{array}{l}\text { gleyic luvisol*, } \\
\text { cambisol*, }^{*} \\
\text { gleysol }^{*}\end{array}$ & $\begin{array}{l}\text { sandy loam, } \\
\text { clay loam, } \\
\text { clay }\end{array}$ & yes & arable \\
\hline Nkedi-Kizza et al. (1983) & 34 & $\begin{array}{l}\text { tritium, } \\
\text { chloride }\end{array}$ & MIM param. & unknown & $\begin{array}{l}\text { oxisol* }^{*} \text { (sieved ag- } \\
\text { gregates) }\end{array}$ & sandy loam & no & irrelevant \\
\hline Oliver and Smettem (2003) & 13 & bromide & $\begin{array}{l}\text { MIM and } \\
\text { CDE param. }\end{array}$ & unknown & $\begin{array}{l}\text { typic } \\
\text { xeric psamment** }\end{array}$ & unknown & no & unknown \\
\hline Pang et al. (2008) & 16 & bromide & MIM param. & 0.975 & $\begin{array}{l}\text { typic dystrudept**, } \\
\text { aeric fragiaquept**, } \\
\text { fluventic } \\
\text { eutrudept**, } \\
\text { typic } \\
\text { udipsamment**, } \\
\text { typic udivitrand }{ }^{* *} \text {, } \\
\text { typic hapludand }\end{array}$ & $\begin{array}{l}\text { clay, } \\
\text { silty clay, } \\
\text { silt loam, } \\
\text { sand, } \\
\text { sandy loam, } \\
\text { loam }\end{array}$ & yes & $\begin{array}{l}\text { managed } \\
\text { grassland }\end{array}$ \\
\hline Perfect et al. (2002) & 2 & chloride & raw data & 0.998 & $\begin{array}{l}\text { typic udifluvent } \\
\text { vertic endoaquept } \\
\text { v* }\end{array}$ & unknown & yes & $\begin{array}{l}\text { managed } \\
\text { grassland }\end{array}$ \\
\hline Pot et al. (2005) & 4 & bromide & MIM param. & 0.988 & stagnosol* & silt loam & yes & $\begin{array}{l}\text { managed } \\
\text { grassland }\end{array}$ \\
\hline
\end{tabular}


Table 1. Continued.

\begin{tabular}{|c|c|c|c|c|c|c|c|c|}
\hline Poulsen et al. (2006) & 33 & tritium & MIM param. & unknown & typic hapludalf** & sandy loam & yes & arable \\
\hline Prado et al. (2006) & 3 & deuterium & CDE param. & unknown & pachic andosol* & silt loam & no & arable \\
\hline Prado et al. (2009) & 9 & deuterium & $\begin{array}{l}\text { MIM and } \\
\text { CDE param. }\end{array}$ & unknown & pachic andosol* & silt loam & yes & arable \\
\hline Raturi et al. (2001) & 6 & bromide & MIM param. & 0.99 & antroposol* & loamy sand & yes & $\begin{array}{l}\text { managed } \\
\text { grassland }\end{array}$ \\
\hline Ren et al. (1996) & 20 & bromide & MIM param. & 0.99 & $\begin{array}{l}\text { durixerollic } \\
\text { calciorthid }^{* *}\end{array}$ & silt loam & yes & arable \\
\hline Reungsang et al. (2001) & 12 & bromide & MIM param. & unknown & $\begin{array}{l}\text { typic } \\
\text { haploaquoll**, } \\
\text { cumulic } \\
\text { haploaquoll }^{* *}\end{array}$ & sandy loam & yes & $\begin{array}{l}\text { managed } \\
\text { grassland, } \\
\text { arable }\end{array}$ \\
\hline Scherr (2009) & 2 & bromide & MIM param. & 0.983 & unknown & silty clay loam & yes & $\begin{array}{l}\text { managed } \\
\text { grassland }\end{array}$ \\
\hline Schoen et al. (1999) & 3 & $\begin{array}{l}\text { bromide, } \\
\text { chloride, } \\
\text { deuterium }\end{array}$ & MIM param. & unknown & unknown & silt loam & yes & arable \\
\hline Schulin et al. (1987) & 23 & $\begin{array}{l}\text { tritium, } \\
\text { bromide }\end{array}$ & MIM param. & unknown & rendzik leptosol* & loam & yes & forest \\
\hline Segal et al. (2009) & 1 & bromide & MIM param. & unknown & unknown & unknown & yes & arable \\
\hline Selim and Amacher (1988) & 3 & tritium & MIM param. & unknown & $\begin{array}{l}\text { aquic fragiudalf**, } \\
\text { typic hapludalf**, } \\
\text { typic } \\
\text { udipsamment** }\end{array}$ & unknown & no & unknown \\
\hline Seo and Lee (2005) & 3 & chloride & MIM param. & unknown & typic hapludult** & sandy loam & yes & unknown \\
\hline Seuntjens et al. (2001) & 2 & chloride & MIM param. & 0.99 & podsol* $^{*}$ & sand & yes & heathland \\
\hline Seyfried and Rao (1987) & 14 & tritium & $\begin{array}{l}\text { MIM and } \\
\text { CDE param. }\end{array}$ & unknown & typic distropept ${ }^{* *}$ & unknown & yes & $\begin{array}{l}\text { arable, } \\
\text { orchard }\end{array}$ \\
\hline Shaw et al. (2000) & 13 & bromide & MIM param. & unknown & kandiudult ${ }^{* *}$ & $\begin{array}{l}\text { sand, } \\
\text { sandy loam, } \\
\text { loamy sand, } \\
\text { sandy clay loam }\end{array}$ & yes & arable \\
\hline Singh and Kanwar (1991) & 6 & chloride & raw data & 0.997 & mesic hapludoll** & unknown & yes & arable \\
\hline Smettem et al., (1983) & 3 & tritium & raw data & 0.973 & unknown & clay loam & yes & arable \\
\hline Smettem (1984) & 12 & tritium & $\begin{array}{l}\text { MIM and } \\
\text { CDE param. }\end{array}$ & unknown & $\begin{array}{l}\text { "well-structured } \\
\text { brown calcareous } \\
\text { earth" }\end{array}$ & silt loam & yes & forest \\
\hline Stagnitti et al. (2000) & 1 & chloride & MIM param. & unknown & unknown & unknown & yes & $\begin{array}{l}\text { managed } \\
\text { grassland }\end{array}$ \\
\hline Tyler and Thomas (1981) & 1 & chloride & raw data & 0.981 & $\begin{array}{l}\text { fluventic } \\
\text { haplodoll**, }^{* *} \\
\text { typic udifluvent**, } \\
\text { vertic haplaquept** }\end{array}$ & $\begin{array}{l}\text { silt loam, } \\
\text { silty clay loam, } \\
\text { sandy loam }\end{array}$ & yes & arable \\
\hline Unold et al. (2009) & 4 & chloride & raw data & 0.996 & $\begin{array}{l}\text { orthic luvisol*, } \\
\text { gleyic cambisol* }^{*}\end{array}$ & $\begin{array}{l}\text { silt loam, } \\
\text { sandy loam }\end{array}$ & yes & arable \\
\hline Vanderborght et al. (2002) & 2 & chloride & MIM param. & unknown & stagnic cambisol $^{*}$ & clay loam & yes & forest \\
\hline Vervoort et al. (1999) & 7 & $\begin{array}{l}\text { bromide, } \\
\text { chloride }\end{array}$ & MIM param. & unknown & typic kandiudult** & $\begin{array}{l}\text { sandy loam, } \\
\text { sandy clay } \\
\text { loam, } \\
\text { clay, } \\
\text { sandy clay }\end{array}$ & yes & $\begin{array}{l}\text { managed } \\
\text { grassland }\end{array}$ \\
\hline Vincent et al. (2007) & 8 & bromide & raw data & 0.994 & stagnosol* & $\begin{array}{l}\text { loam, } \\
\text { silt loam }\end{array}$ & yes & $\begin{array}{l}\text { arable, } \\
\text { managed } \\
\text { grassland, } \\
\text { forest }\end{array}$ \\
\hline Vogeler et al. (2006) & 12 & $\begin{array}{l}\text { bromide, } \\
\text { chloride }\end{array}$ & CDE param. & unknown & stagnic luvisol* $^{*}$ & sandy loam & yes & arable \\
\hline Wilson et al. (1998) & 2 & bromide & raw data & 0.972 & typic paleudalf** & silt loam & yes & arable \\
\hline Zurmühl (1998) & 2 & tritium & MIM param. & unknown & unknown & sand & yes & forest \\
\hline
\end{tabular}

* Classification according to the World Reference Base (WRB). ** Classification according to the system of the United States Department of Agriculture (USDA). 
conditions collected in the database as well as information on their completeness.

One difficulty in comparing experimental data is that several different soil texture classification systems were used in the 76 articles. All the classification systems have in common that they assign all particles with an equivalent diameter of less than two micrometers to the clay fraction, but the boundary between the silt and sand fraction varies. We standardized all texture data to the USDA classification system, which sets the silt/sand boundary at $50 \mu \mathrm{m}$. We did this by log-linear interpolation (Nemes et al., 1999). For soil columns containing two or more soil layers, we derived an effective soil textural composition by calculating the layer-thickness-weighted average of the sand, silt and clay fractions, respectively. In addition, we computed the geometric mean grain diameter using the approach published in Shirazi et al. (2001).

Another difficulty in comparing the shapes of different BTCs arises from the fact that the pulse length during which the tracer was applied varies with the corresponding source publication. It is therefore necessary to normalize the BTCs to a standard tracer application. We chose a Dirac-like input as our standard. For this type of tracer application, the traveltime probability density function (PDF) of the tracer at the measurement location can be derived by simple scaling. This process is denoted as BTC-deconvolution in the following. For the BTC-deconvolution, a transfer-function $f\left(\mathrm{~d}^{-1}\right)$ is sought, which describes the BTC (here denoted as $C_{\text {out }}(-)$ ) for a given tracer application function $C_{\text {in }}(-)$ :

$C_{\text {out }}=\int_{0}^{\infty} C_{\text {in }}(t-\tau) f(\tau) \mathrm{d} \tau$.

The solute concentrations $C_{\text {out }}$ and $C_{\text {in }}$ were normalized to a reference concentration. They are therefore dimensionless. We also standardized all time variables including $t$ (d) and $\tau$ (d) in Eq. (1) to days. Due to the normalizations of times and concentrations, the transfer-function, $f$, is also the travel-time probability density function (PDF) of the tracer. It is important to note that $f$ does not (necessarily) describe the evolution of the BTC along the travel trajectory. Our study only requires that $f$ fits Eq. (1) at the location of the measurement, namely at the outlet of the soil columns. This allows us to use arbitrary transfer-function types to estimate the PDF of the BTC, as long as it is able to fit the BTC data well enough.

One advantage of this is that we can use CDE and MIM parameter sets to reconstruct the PDF, $f$. By using CDE and MIM parameter sets, we were able to also include studies in which only MIM or CDE model parameters were reported rather than raw data of the actual BTCs. We only considered BTCs for which the corresponding model could be fitted with a coefficient of determination $R^{2}>0.95$. Note that for some BTCs, no measure of goodness of fit is given. In these cases we assumed that the fit was sufficient if the MIM was used alone or alongside the CDE (as e.g. in Seyfried et al., 1987).
Otherwise, we decided by visual inspection whether the CDE fitted the BTC well enough to be included in our study. As a result, 733 BTCs were investigated in the following.

The 733 BTCs in our database consist of 146 BTCs scanned from raw data, 399 BTCs for which only MIM parameters were available and 188 BTCs for which CDE parameters were published. For the 146 datasets for which the BTC raw data was available, MIM parameters were inversely determined by fitting CXTFit 2.1 (Toride et al., 1999, command-line version published as part of the STANMOD package, version 2.07). We included this step to make the 146 datasets with BTC raw data more comparable to the remaining 587 BTCs for which only model parameters were available. A drawback to this approach is that some PDFs are then only reconstructed in an approximate manner due to the limited degrees of freedom of the MIM transfer-function and its inability to fit some of the BTCs. Nevertheless, the MIM and CDE fitted the BTC very well in most cases, with a geometric mean coefficient of determination, $R^{2}$, of 0.99 . Alternative methods for PDF-reconstruction could be preferable in those few cases where the CDE or MIM did not fit well. For example, the BTCs could be deconvoluted using a mixture of standard-type transfer functions (see e.g. Koestel et al., 2011) or by imposing a smoothness constraint (Skaggs et al., 1998).

We used the analytical solutions of the CDE and MIM for Dirac-pulse input, flux concentrations in input and effluent and a semi-infinite domain (Valocchi, 1985) to forwardmodel PDFs. We then derived four non-parametric shapemeasures from the reconstructed PDFs (Koestel et al., 2011) to evaluate the respective solute transport properties. We especially focused on indicators of preferential solute transport.

According to Hendrickx and Flury (2001), preferential flow and transport processes comprise "all phenomena where water and solutes move along certain pathways while bypassing a fraction of the porous matrix". An operational definition of preferential transport is a mixing regime that is not convective-dispersive, which assumes complete mixing in the directions transverse to the flow (Flühler et al., 1996). For a convective-dispersive mixing regime, the transport is described by the CDE. However, it is not possible to test the validity of the CDE with the type of data collated in our study, comprising breakthrough curves measured at one only travel distance (Jury and Roth, 1990). We therefore make use of the shape-measures as simple indicators of the strength of preferential transport and "early tracer arrival" relative to piston-flow. It should be noted that a shape-measure indicating early tracer arrival cannot tell us whether the transport process could have been described by the CDE with a large dispersion coefficient or not.

The first indicator we investigated is the ratio of the pistonflow velocity, $v_{q}\left(\mathrm{~cm} \mathrm{~d}^{-1}\right)$, to the average transport velocity, 
Table 2. Inventory of the data available in the database.

\begin{tabular}{lll}
\hline Data & Available & Missing \\
\hline Explicit information on water content, $q\left(\mathrm{~cm}^{3} \mathrm{~cm}^{-3}\right)$ & 487 & 246 \\
Explicit information on water flux, $q\left(\mathrm{~cm} \mathrm{~d}^{-1}\right)$ & 551 & 182 \\
Travel distance, $L(\mathrm{~cm})$ & 733 & 0 \\
Area of breakthrough plane, $A\left(\mathrm{~cm}^{2}\right)$ & 733 & 0 \\
Information on tracer detection method & 733 & 0 \\
Information on initial conditions & 731 & 2 \\
Pressure head at upper boundary, $h_{\mathrm{UB}}(\mathrm{cm})$ & 333 & 400 \\
Pressure head at lower boundary, $h_{\mathrm{LB}}(\mathrm{cm})$ & 429 & 304 \\
Average pressure head, $h_{\text {ave }}(\mathrm{cm})$ & 466 & 267 \\
Hydraulic gradient, $\mathrm{d} H / L(-)$ & 406 & 327 \\
Information on irrigation device & 708 & 25 \\
Information on outlet construction & 694 & 39 \\
Information on tracer & 733 & 0 \\
Information on tracer application method & 733 & 0 \\
BTC raw data & 146 & 587 \\
Information on land use & 635 & 98 \\
Information on cropping & 454 & 279 \\
Information on soil management practices & 388 & 345 \\
Depth from which soil sample was collected $(\mathrm{cm})$ & 508 & 225 \\
Texture data & 618 & 115 \\
Bulk density, $\rho$ (g cm ${ }^{-3}$ ) & 605 & 128 \\
Organic carbon content, OC $(-)$ & 488 & 245 \\
Porosity, $f\left(\mathrm{~cm}^{3} \mathrm{~cm}{ }^{-3}\right.$ ) & 611 & 122 \\
\hline
\end{tabular}

$v_{n}\left(\mathrm{~cm} \mathrm{~d}^{-1}\right)$, denoted as $\eta(-)$ and defined by

$\eta=\frac{v_{q}}{v_{n}}$

where

$v_{q}=\frac{q}{\theta}$

and

$v_{n}=\frac{L}{\mu_{1}^{\prime}}$

where $q\left(\mathrm{~cm} \mathrm{~d}^{-1}\right)$ is the water flux, $\theta$ is the (total) volumetric water content (-), $L$ is the column length $(\mathrm{cm})$ and $\mu_{1}^{\prime}$ is the normalized first moment of the PDF,

$\mu_{1}^{\prime}=\frac{m_{1}}{m_{0}}$

where $m_{0}$ and $m_{1}$ are the zeroth and first moments of the PDF, $f$, respectively, defined as

$m_{0}=\int_{0}^{\infty} f \mathrm{~d} t$

and

$m_{1}=\int_{0}^{\infty} t f \mathrm{~d} t$.
The piston-flow to transport velocity ratio, $\eta$, is smaller than one if the solute is transported faster than the water; it is larger than one if the solute is retarded relative to the water. It is a non-parametric analogue to the retardation coefficient in the CDE and MIM. Vanderborght and Vereecken (2007) used the reciprocal of $\eta$ (i.e. $1 / \eta$ ) to investigate preferential transport. They suggested that $\eta<1$ indicates bypass flow.

The second shape-measure used in this study is the normalized arrival-time of the first five percent of the tracer, $p_{0.05}(-)$. It can be derived from the normalized arrival times, $T(-)$,

$T=\frac{t}{\mu_{1}^{\prime}}$

and the normalized PDF, $f_{\mathrm{n}}(-)$,

$f_{\mathrm{n}}=f \mu_{1}^{\prime}$.

It is more easily obtained from the dimensionless cumulative distribution function $(\mathrm{CDF}), F_{\mathrm{n}}(-)$, which is calculated by integrating $f_{\mathrm{n}}$ :

$F_{\mathrm{n}}=\int_{0}^{T} f_{\mathrm{n}} \mathrm{d} T$.

Figure 1 illustrates how $p_{0.05}$ is derived for a BTC taken from Garré et al. (2010). $p_{0.05}$ is bounded by zero and one, where 
a)

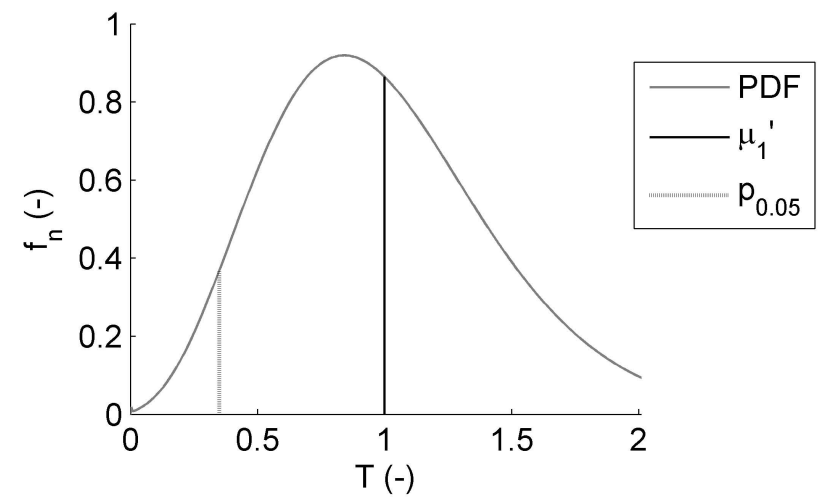

b)

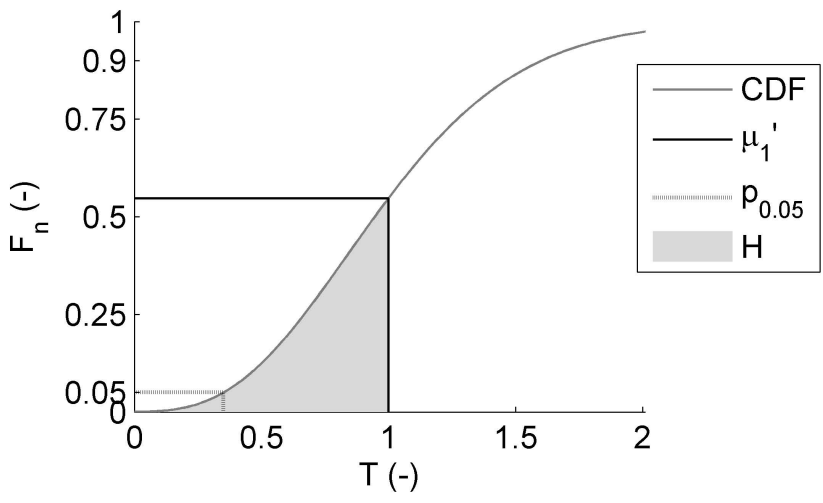

Fig. 1. The PDF (a) and CDF (b) of an example BTC taken from Garré et al. (2010) illustrating how the normalized first temporal moment, $\mu_{1}^{\prime}$, the normalized $5 \%$-arrival time, $p_{0.05}$, and the holdback, $H$, are derived.

a value of one indicates piston flow. According to the numerical studies carried out by Knudby and Carrera (2005), $p_{0.05}$ is negatively correlated with the degree of preferential transport, since small $p_{0.05}$ indicate an early tracer arrival. The results of Koestel et al. (2011) indicate that early tracer arrivals are correlated with a long tailing. Note that these two BTC shape-features, early tracer arrival and a long tailing, are generally associated with preferential transport (see Brusseau and Rao, 1990).

We also investigated the holdback factor, $H(-)$, as another indicator of early tracer arrival. It was introduced by Danckwerts (1953) to characterize the degree of mixing of two solutes in a vessel. $H$ is calculated as the integral of the dimensionless $\mathrm{CDF}$ between zero and one:

$H=\int_{0}^{1} F_{\mathrm{n}} \mathrm{d} T$.

It corresponds to the "amount of original fluid remaining in the column when one (water-filled) pore volume of displacing fluid has entered" (Rose, 1973). It follows that a large $H$ should indicate preferential characteristics in a transport process. The holdback factor, $H$, is illustrated in Fig. 1. $H$ has the advantage over $p_{0.05}$ that it samples a larger part of the $\mathrm{CDF}$, but has the disadvantage that it is less robust to the type of transfer-function chosen for the BTC-deconvolution (Koestel et al., 2011).

Finally, we also investigated the apparent dispersivity, $\lambda_{\text {app }}$ $(\mathrm{cm})$, which is defined as

$\lambda_{\text {app }}=\frac{\mu_{2} L}{2}$

where $\mu_{2}(-)$ is the second central moment of the normalized PDF,

$\mu_{2}=\int_{0}^{\infty}(T-1)^{2} f_{\mathrm{n}} \mathrm{d} T$.

Note that $\mu_{2}$, as it is defined here, is identical to the squared coefficient of variation. The apparent dispersivity, $\lambda_{\text {appp }}$, is generally thought to be an indicator of heterogeneity of the solute transport process (Vanderborght and Vereecken, 2007). Koestel et al. (2011) found that $\lambda_{\text {app }}$ is correlated to $p_{0.05}$ and $H$, but also carries additional information on the transport process and thus may complement the above discussed shape-measures. Because the additional information contained in $\lambda_{\text {app }}$ stems from the late-arriving tracer, it has the disadvantage that it is less robust to the type of transfer-function chosen for the BTC-deconvolution than $p_{0.05}$ (Koestel et al., 2011), i.e. $\lambda_{\text {app }}$ is less well defined by the BTC-data than $p_{0.05}$ and $H$. One advantage of $\lambda_{\text {app }}$ as a shape measure is that it has already been intensively investigated in the literature (Bromly et al., 2007; Vanderborght and Vereecken, 2007; Hunt and Skinner, 2010).

\section{Results and discussion}

302 of the 733 experiments available in the database correspond to soil samples from arable land (Table 3). 299 of them were conducted on undisturbed soil samples. 219 of them are from conventionally-tilled fields, 6 from fields with reduced or conservation tillage and 31 from fields with no tillage at all. For the remaining 46 samples, the soil management practices were not specified. Managed or natural grassland is the second most common land use type represented in the database $(n=104)$. Samples with arable and grassland land use are distributed over most of the texture triangle with no apparent bias towards any textural class (see Fig. 2). In contrast, the 79 BTCs from samples from forest sites are restricted to soil samples with less than $25 \%$ clay (Fig. 2). Other land uses, like orchard $(n=19)$, grass ley $(n=7)$ or heathland $(n=2)$, are rare. 98 BTCs were measured on samples with unspecified land use. Finally, the 733 datasets also contain 116 experiments on sieved and repacked columns, 32 experiments on columns filled with clean sands or glass beads and 60 experiments on undisturbed samples 
Table 3. Land use and soil management for the 733 datasets in the database.

\begin{tabular}{lr}
\hline Land use & $\begin{array}{r}\text { \# of entries } \\
\text { in the database }\end{array}$ \\
\hline arable (all) & 302 \\
arable (conventional tillage) & 219 \\
arable (reduced tillage) & 6 \\
arable (no tillage) & 31 \\
arable (no further information) & 46 \\
forest & 79 \\
managed grassland & 92 \\
natural grassland & 12 \\
grass ley & 7 \\
heathland & 2 \\
orchard & 19 \\
unknown land use & 98 \\
sieved and repacked samples* & 116 \\
unconsolidated bedrock & 60 \\
clean sand or glass beads & 32 \\
\hline
\end{tabular}

* Note that for some of the sieved samples the land use was known.

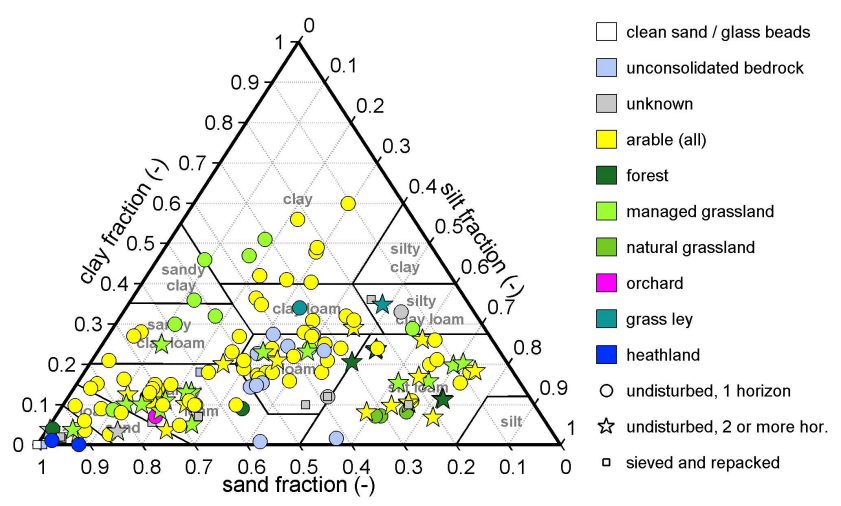

Fig. 2. Land uses corresponding to the soil samples on which the 733 considered BTC experiment had been carried out. Note that in most publications only average values are published for several soil samples and that several experiments are often conducted on one and the same soil sample under different hydraulic boundary conditions. Therefore, the number of datasets visible in the texture triangle is less than 733 .

taken from more than $1 \mathrm{~m}$ below the land surface (Table 3 ). Figure 2 illustrates that the majority of the solute transport experiments had been performed on undisturbed but rather short soil columns, which had been sampled from one single soil horizon.

An overview of Spearman rank correlations among the investigated soil properties, experimental conditions, and BTC shape measures is given in Fig. 3. The asterisks indicate $p$ values of less than 0.001 . Some correlations are unsurprising, such as the positive correlations between the flux, $q$, the average transport velocity, $v$, the average pressure head, $h$, and the water content, $\theta$. Other similar examples are the cor-

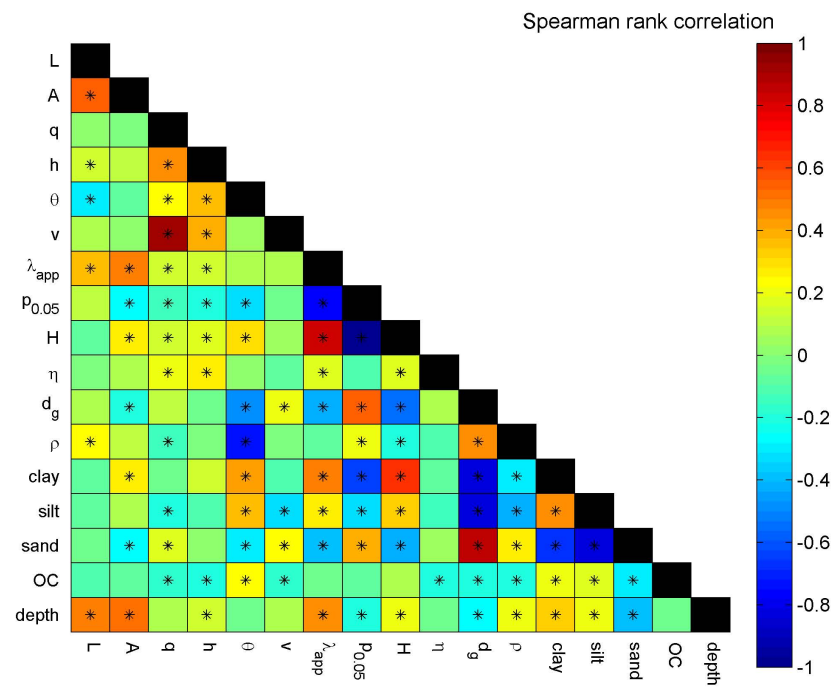

Fig. 3. Spearman rank correlation coefficients between various BTC-shape measures and soil and site as well as experimental properties. The boxes marked by an asterisk indicate significant correlations with $p$-values smaller than 0.001 . The correlations were carried out for the travel distance, $L$, the area of the breakthrough plane, $A$, the water flux, $q$, the suction head, $h$, the water content, $\theta$, the transport velocity, $v$, the apparent dispersivity, $\lambda_{\text {app }}$, the normalized $5 \%$-arrival time, $p_{0.05}$, the holdback, $\mathrm{H}$, the piston-flow to transport velocity ratio, $\eta$, the geometric mean grain diameter, $d_{\mathrm{g}}$, the soil bulk density, $\rho$, the clay fraction, clay, the silt fraction, silt, the sand fraction, sand, the organic carbon content, OC, the average sampling depth, and depth.

relations between geometric mean grain diameter, $d_{\mathrm{g}}$, bulk density, $\rho$, and clay, silt, and sand fractions. Also, the positive correlation between average sampling depth and the soil sample length (which is identical to the travel distance), $L$, is easily explained, as sampling pits for larger soil columns must necessarily extend deeper into the ground. Likewise, the column cross-section, $A$, is positively correlated with $L$ (and the sampling depth).

We found a positive correlation of the apparent dispersivity, $\lambda_{\text {app }}$, with travel distance, $L$, and lateral observation scale, $A$. This confirms what has been in general found in already published reviews on dispersivity (e.g. Gelhar et al., 1992; Vanderborght and Vereecken, 2007), although it is hardly possible to separate the effects of $L$ and $A$ on $\lambda_{\text {app }}$ due to their large mutual correlation. Also consistent with previous studies, Fig. 3 shows a positive correlation between the apparent dispersivity, $\lambda_{\text {app }}$, and the water flux, $q$, as well as the pressure head, $h$. Furthermore, the correlation coefficients with texture data show that $\lambda_{\text {app }}$ was in general larger for finer textured soil and smaller for coarse textures, which also is in accordance with empirical knowledge and is also supported by the data shown in Vanderborght and Vereecken (2007) for larger water flow rates. Finally, we 
observed no correlation between organic carbon content, OC, and apparent dispersivity, $\lambda_{\text {app }}$.

Two of the three investigated indicators of early tracer arrival, namely the normalized $5 \%$-arrival time, $p_{0.05}$, and the holdback factor, $H$, were strongly negatively correlated. This confirms the findings of Koestel et al. (2011) on a smaller dataset. According to these two shape-measures, the degree of preferential transport increased with flux, $q$, pressure head, $h$, and water content, $\theta$. This is consistent with empirical findings that show that preferential flow and transport are more likely to be observed under saturated and near-saturated conditions (Langner et al., 1999; Seyfried and Rao, 1987). The correlation matrix indicates that the degree of preferential transport was positively correlated with the lateral observation scale, $A$, but not with the transport distance, $L$. An intuitive explanation for this is that increasing the lateral observation scale also increases the probability of sampling preferential flow paths, whereas an increase in transport distance decreases the probability of connected preferential flow paths in the transport direction. We consider it likely that a negative correlation between transport distance and preferential transport characteristics was masked by the strong mutual correlation between $L$ and $A$. Both shape-measures, $p_{0.05}$ and $H$, indicate a positive correlation between the degree of preferential transport and the clay and silt fraction, and a negative correlation to the geometric mean grain diameter and the sand fraction. Also, a weak negative correlation between the strength of preferential transport and bulk density, $\rho$, was found. The organic carbon content, OC, was not correlated to $p_{0.05}$, but a weak negative correlation with $H$ was found. The latter may be explained by smaller water flow rates for the experiments with larger organic carbon contents, OC. The correlation between OC and the piston-flow to transport velocity ratio, $\eta$, points in the opposite direction as it is also negative, albeit weak.

The fourth shape-measure, the piston-flow to transport velocity ratio, $\eta$, was not significantly correlated to the normalized $5 \%$-arrival time, $p_{0.05}$. A very weak positive correlation was found between $\eta$ and the holdback factor $H$ and to the apparent dispersivity, $\lambda_{\text {app }}$. Moreover, we observed that solute transport was increasingly retarded $(\eta>1)$ with increasing water flow rate, $q$, and pressure heads, $h$. We found no significant correlations between $\eta$ and any of the investigated soil properties (i.e. geometric mean grain diameter, $d_{\mathrm{g}}$, bulk density, $\rho$, texture fractions and organic carbon content, OC). It follows that the piston-flow to transport velocity ratio, $\eta$, reflects different information on solute transport characteristics as compared to the other indicators for early tracer arrival, $p_{0.05}$ and $H$.

Figure $4 \mathrm{a}$ shows that the correlation between the $5 \%$ arrival time, $p_{0.05}$, and the holdback factor, $H$, was weaker for small $p_{0.05}(\operatorname{large} H$ ), i.e. for BTCs displaying strong preferential transport. Figure 4 a suggests that $H$ offers a better discrimination between soils showing strong preferential transport, whereas $p_{0.05}$ better resolves differences among
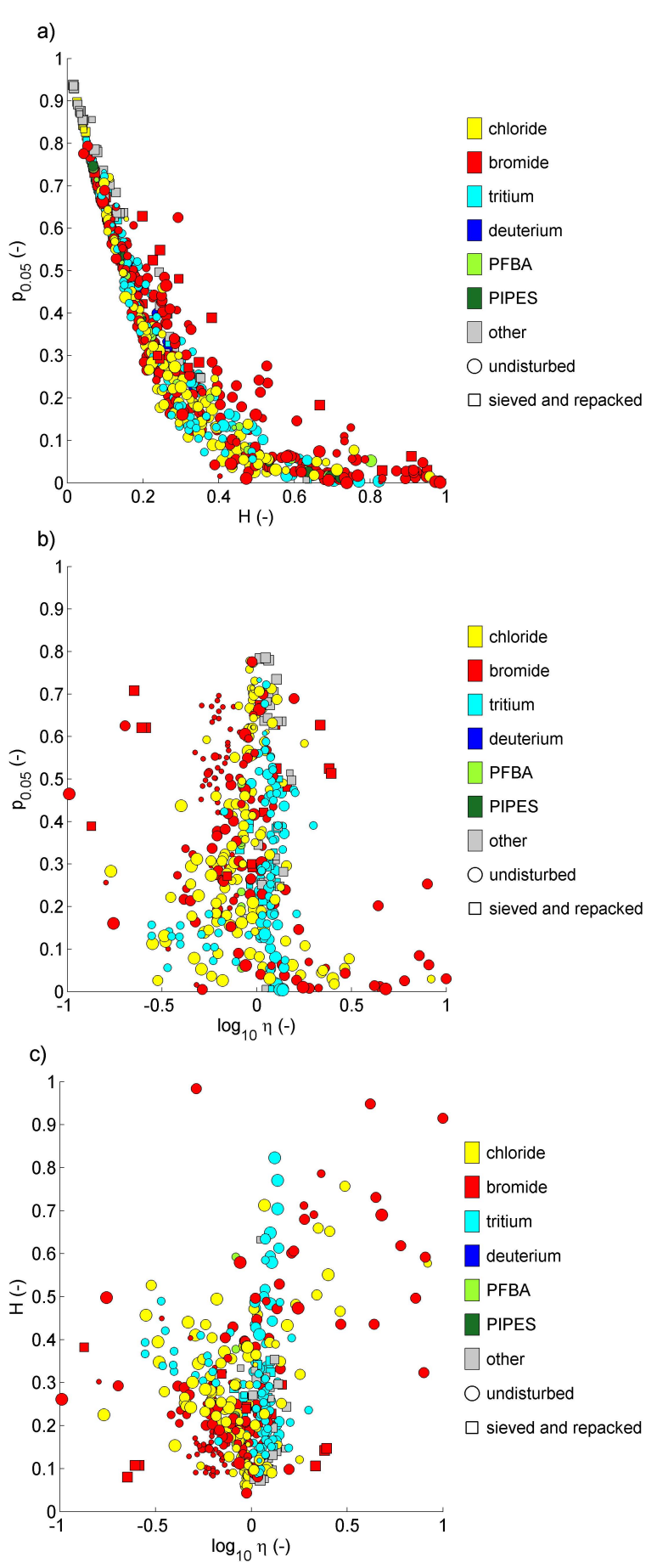

Fig. 4. Comparison between the shape-measures related to early tracer arrival: (a) comparison between the holdback, $H$, and the normalized $5 \%$-arrival time, $p_{0.05}$; (b) comparison of the pistonflow to transport velocity ratio, $\eta$, and the normalized $5 \%$-arrival time, $p_{0.05}$; (c) comparison of the piston-flow to transport velocity ratio, $\eta$, and the holdback, $H$. In addition, the type of applied tracer is depicted. The symbol size corresponds to the water fluxes, $q$, under which the experiment was conducted, small symbols indicating small water fluxes, large symbols denoting large water fluxes. 
soils with weaker preferential transport characteristics. In Fig. $4 \mathrm{~b}$ and $\mathrm{c}$, the piston-flow to transport velocity ratio, $\eta$, is compared to $p_{0.05}$ and $H$. Note that no value for $\eta$ was available if no independent water content measurement was published for the respective BTC (see Eq. 2). Therefore, the range of $p_{0.05}$ in Fig. $4 \mathrm{~b}$ appears to be different to the one in Fig. 4a. Besides depicting the minimal correlation of $\eta$ to the other two indicators of early tracer arrival, these two figures also illustrate that $\eta$ was, in contrast to $p_{0.05}$ and $H$, sensitive to the choice of tracer in the BTC experiments. Anionic tracers like chloride and bromide were generally transported faster than the water flux, whereas the electrically neutral tracers deuterium and tritium only occasionally exhibited accelerated transport, namely when small $p_{0.05}$ and medium $H$ indicated preferential characteristics. As we only considered experiments where the anionic tracers were applied on soils with electrically neutral or predominantly negatively charged media, the generally accelerated solute transport for anionic tracers is well explained by anion exclusion (Rose et al., 2009; Thomas and Swoboda, 1970). Notably, for very strong preferential transport $\left(p_{0.05}<0.1\right.$ and $\left.H>0.4\right)$, the anionic tracers were retarded.

Figure 5a illustrates that, for a given value of $\lambda_{\text {app }}, p_{0.05}$ increases with the column length, $L$. This suggests that the strength of preferential transport decreases with travel distance. No significant correlation was found between $L$ and $p_{0.05}$ (Fig. 3), probably because it was masked by the nonlinearity of the ternary relationship between $L, p_{0.05}$ and $\lambda_{\text {app }}$, especially for strong preferential transport $\left(p_{0.05}<\right.$ 0.1 ). A principal component analysis revealed that the first two principal components for the $\log _{10} L$ and the two shapemeasures $\log _{10} \lambda_{\text {app }}$ and $p_{0.05}$ (normalized to a mean of zero and a standard deviation of one) explain $91.9 \%$ of the variance between the three shape-measures. In contrast, the first principal component of just $\log _{10} \lambda_{\text {app }}$ and $\log _{10} L$ explains only $66.2 \%$ of the variance, exhibiting a Spearman rank correlation coefficient of 0.369 ( $p$-value $<0.001$ ). Thus, including $p_{0.05}$ into a scaling-scheme for the apparent dispersivity, $\lambda_{\text {app }}$, with travel distance, $L$, strongly increases the amount of explained variance. A very similar ternary relationship was found between $\log _{10} \lambda_{\mathrm{app}}, p_{0.05}$, and the logarithm of the area of the breakthrough plane, $\log _{10} A$ (Fig. 5b), which explained $88.7 \%$ of the inherent variance. The first principal component between only $\lambda_{\text {app }}$ and $A$ explains $70.3 \%$ of the variance. The corresponding Spearman rank correlation coefficient is 0.5 ( $p$-value $<0.001)$.

Figure 6a-d show the dependency of $v, \lambda_{\text {app }}, p_{0.05}$, and $\eta$ on water flow rates. Only undisturbed samples were considered. Figure $6 \mathrm{a}-\mathrm{c}$ show that not only the medians of $v$ and $\lambda_{\text {app }}$ monotonically increase with the respective water flux class but also the strength of preferential transport (there is negative relationship between $p_{0.05}$ and $q$ ). Note that correlation effects between water flow rate, $q$, and travel distance, $L$, and lateral observation scale, expressed by $A$, are ruled out since these quantities were not correlated (Fig. 3). For undis-
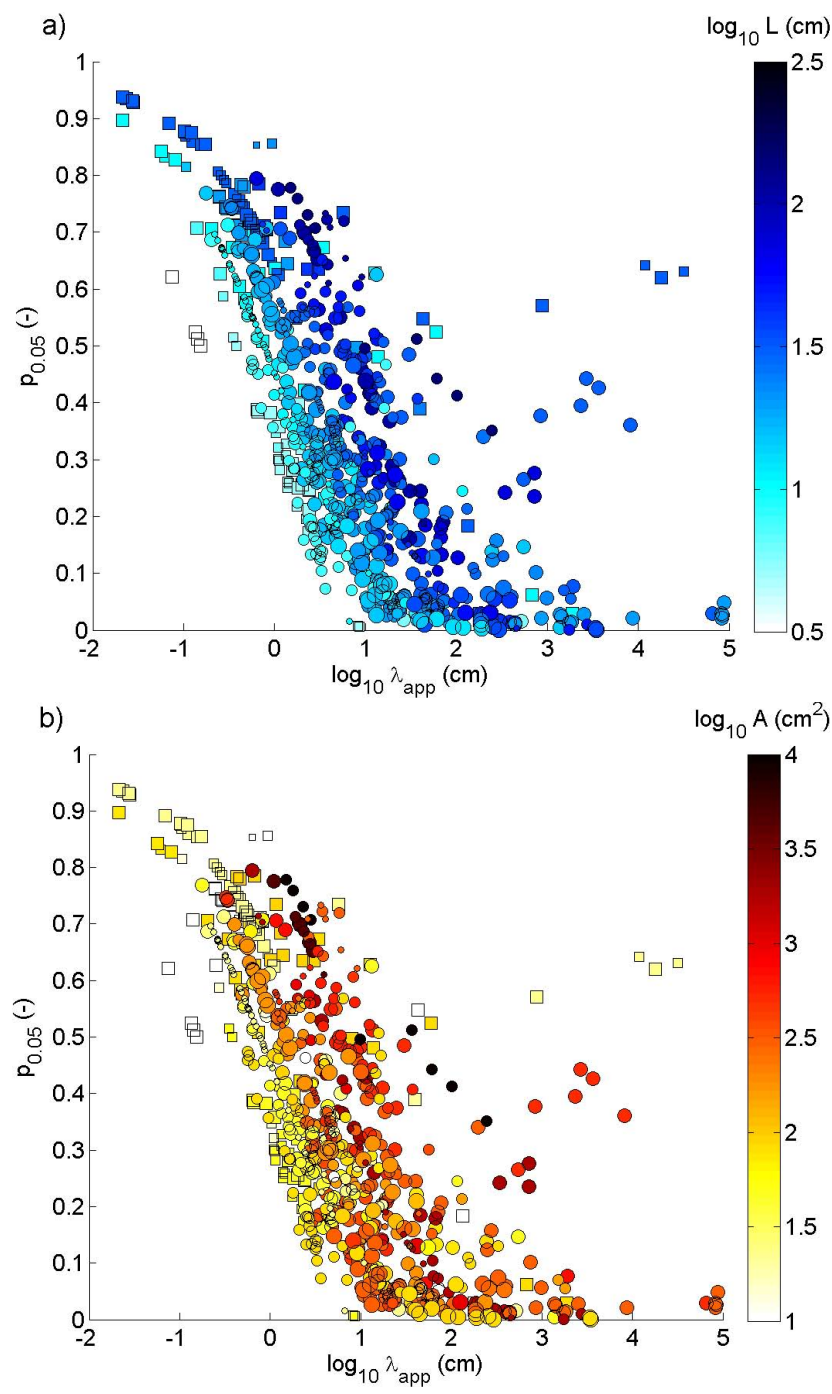

Fig. 5. Comparison of the apparent dispersivity, $\lambda_{\text {app }}$, and normalized $5 \%$-arrival time, $p_{0.05}$, with (a) the travel distance, $L$, and (b) the area of the breakthrough plane, $A$. The symbol size corresponds to the water fluxes, $\mathrm{q}$, under which the respective experiment was conducted, small symbols indicating small water fluxes, large symbols denoting large water fluxes. The meaning of the symbol shape is explained in Fig. 4.

turbed samples only, we found a significant but very weak positive correlation between the water flow rate, $q$, and the clay content (Spearman rank correlation coefficient is 0.15 , not shown). Therefore, we conclude that the water flow rate was the most important factor for the relationships shown in Fig. 6a-c. This suggests that, for this dataset, macropore transport overshadows preferential transport caused by heterogeneities in matrix hydraulic properties. Nevertheless, Fig. $6 \mathrm{c}$ also illustrates that preferential transport cannot be completely ruled out for small water fluxes. Little dependence of the piston-flow to transport velocity ratios, $\eta$, on the water flux, $q$, was observed (Fig. 6d). This suggests that 


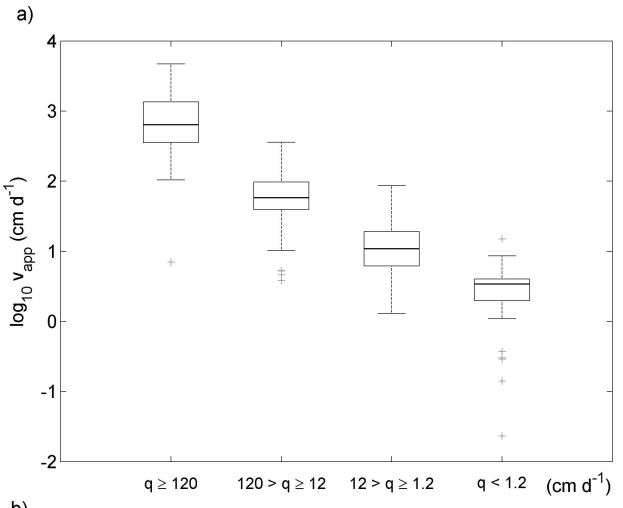

b)

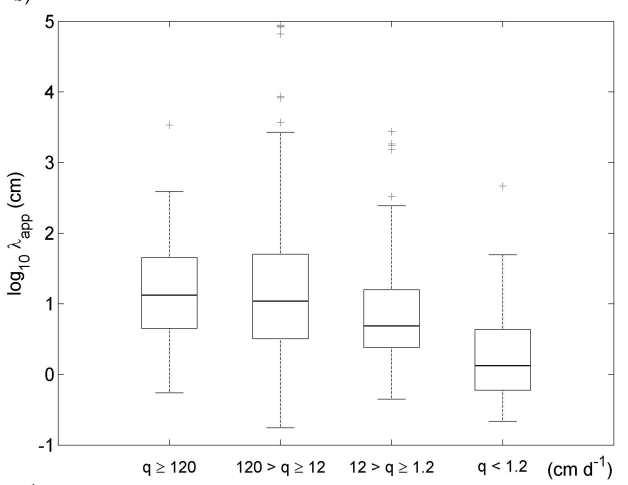

c)
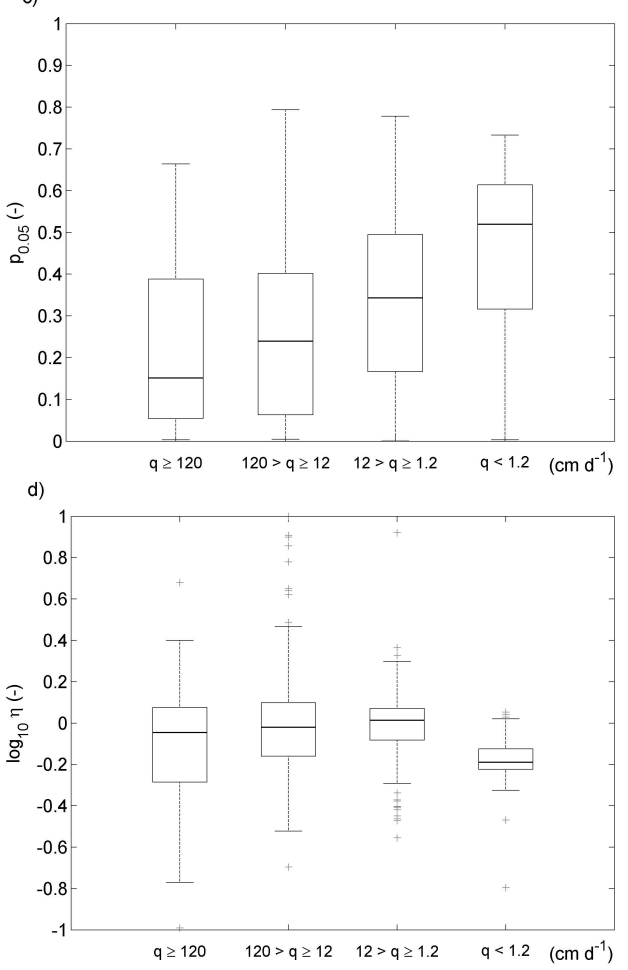

Fig. 6. Boxplots (a) transport velocity, $v$, (b) apparent dispersivity, $\lambda_{\text {app}},(\mathbf{c})$ normalized $5 \%$-arrival time, $p_{0.05}$, and (d) piston-flow to transport velocity ratio, $\eta$ according to the respective water flux class. Note that this figure is based on BTCs from undisturbed soil samples only.

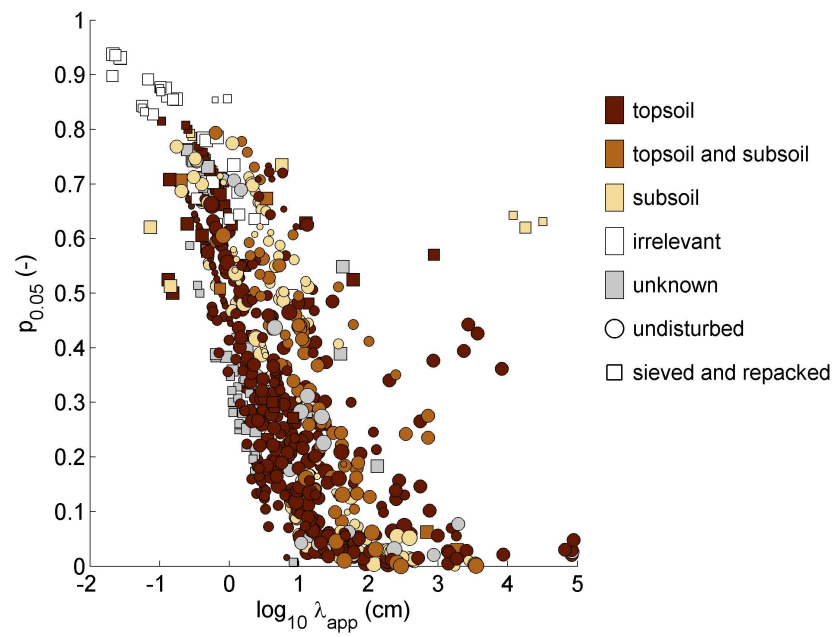

Fig. 7. Comparison of the apparent dispersivity, $\lambda_{\text {app }}$, and normalized $5 \%$-arrival time, $p_{0.05}$, with sampling location of the respective soil sample. The symbol size corresponds to the water fluxes, $q$, under which the respective experiment was conducted, small symbols indicating small water fluxes, large symbols denoting large water fluxes.

$\eta$ is not strictly related to preferential transport in soil macropores. Indeed, $\eta$ is smallest for the experiments with the lowest water fluxes. As most of the experiments included in this analysis were conducted with anionic tracers, a possible explanation for this behaviour is that anion exclusion was amplified for experiments under small water flow rates, which by trend correspond to experiments under far from saturated conditions when only meso- and micropores are water-filled.

Figure 7 depicts how the soil horizon, from which the sample had been taken, is related to $\lambda_{\text {app }}$ and $p_{0.05}$. Firstly, Fig. 7 illustrates that samples that contain both topsoil and subsoil exhibit larger apparent dispersivities, $\lambda_{\text {app }}$, than samples from only topsoil or only subsoil. One obvious explanation for this is that samples containing both topsoil and subsoil are generally longer, so that $\lambda_{\text {app }}$ is also larger due to its positive correlation with travel distance (see Fig. 5a). However, it is also plausible that features at the interfaces between topsoil and subsoil in these columns, e.g. plow pans, enhance the spreading of a solute plume, such as observed for example by Öhrström et al. (2002) and Koestel et al. (2009b). As samples taken from only the topsoil are always restricted to lengths between 20 and $40 \mathrm{~cm}$ and because longer samples taken from only the subsoil have seldom been investigated, it is not possible to appraise to what degree interfaces between topsoil and subsoil add to the scaling effect of the apparent dispersivity, $\lambda_{\text {app }}$, with travel distance. Furthermore, soil columns filled with clean sands or glass beads, which are tagged as "irrelevant" in Fig. 7, generated strictly nonpreferential BTCs.

The relationship between $\lambda_{\text {app }}$ and $p_{0.05}$ and soil texture, characterized by the geometric mean grain diameter, $d_{\mathrm{g}}$, is 


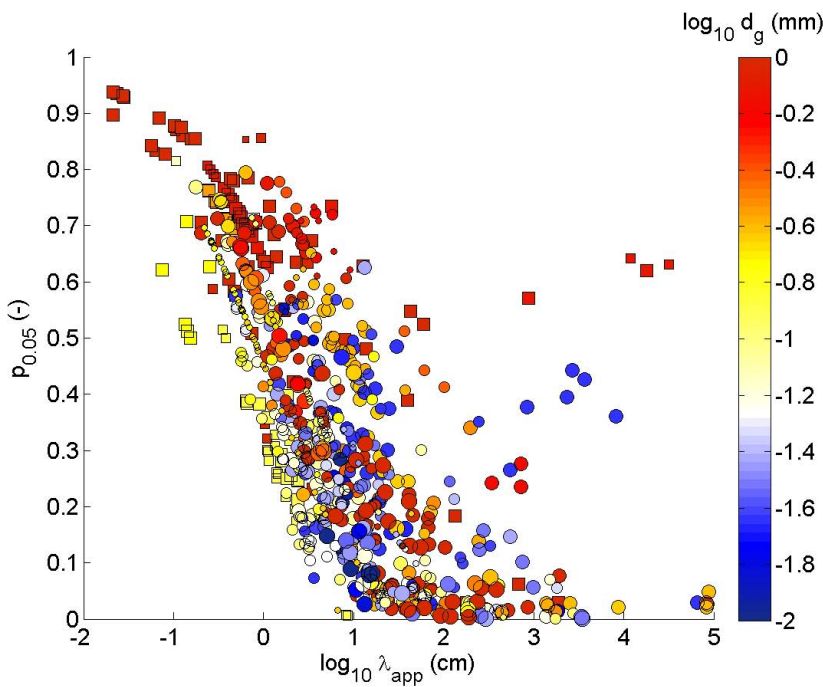

Fig. 8. Comparison of the apparent dispersivity, $\lambda_{\text {app }}$, and normalized $5 \%$-arrival time, $p_{0.05}$, with the geometric mean grain diameter, $d_{\mathrm{g}}$, of the respective soil sample. The symbol size corresponds to the water fluxes, $q$, under which the respective experiment was conducted, small symbols indicating small water fluxes, large symbols denoting large water fluxes. The meaning of the symbol shape is explained in Fig. 4.

somewhat more complicated (see Fig. 8). Coarser-textured soils with large $d_{\mathrm{g}}$ are not at all restricted to a specific range of apparent dispersivities or $5 \%$-arrival times, or specific combinations of the two. In contrast, for fine-grained soils, $p_{0.05}$ is always less than 0.6 and the apparent dispersivity always exceeds ca. $2 \mathrm{~cm}$. Finally, the samples with an intermediate $d_{\mathrm{g}}$ show low $p_{0.05}$-to- $\lambda_{\text {app }}$ ratios upon visual inspection (Fig. 8). Such a ratio is also typical for short transport distances (Fig. 5a). A possible explanation may be that, in our dataset, experiments on soils with intermediate $d_{\mathrm{g}}$ were only carried out on short columns. In summary, there are no smooth transitions apparent in Fig. 8 and the geometric mean grain diameter appears not to be a strong predictor for $\lambda_{\text {app }}$ and $p_{0.05}$.

A clearer picture emerges if $\lambda_{\text {app }}$ and $p_{0.05}$ are plotted in relation to USDA texture classes. Figure 9a shows that BTCs showing strong preferential transport characteristics $\left(p_{0.05}<0.2\right)$ are restricted to samples containing at least 8 to $9 \%$ clay. This is similar to the clay content needed for the formation of stable soil aggregates (Horn et al., 1994) and may also reflect an absence of biopores in soils with less than $9 \%$ clay, since both roots and earthworms generally avoid coarse single-grain soils. Notably, Quisenberry et al. (1993) used a clay content of $8 \%$ as the first criterion for a decision tree for classifying water and solute transport characteristics of soil, although they only presented 11 measurements to support the choice of this threshold. Our study confirms their conjecture.
Small $p_{0.05}$ values are less common for samples with more than $50 \%$ silt. However, the latter may possibly be an artifact caused by the scarcity of experiments on short columns sampled from just one single soil horizon in silty soils (see Fig. 9d). The apparent dispersivity, $\lambda_{\text {app }}$, roughly follows the distribution of $p_{0.05}$ on the texture triangle diagram (Fig. 9b), which is not surprising given the strong correlation between the two (see Fig. 5). However, extreme $\lambda_{\text {app }}$ values were less clearly constrained to specific regions on the texture triangle diagram. They mostly occurred for undisturbed samples containing more than one soil horizon. Finally, Fig. 9c shows the distribution of the piston-flow to transport velocity ratio, $\eta$ on the texture triangle. Small piston-flow to transport velocity ratios $(\eta \ll 1)$ were predominantly found for loamy soils and were absent for soils in which one of the three fractions (silt, sand or clay) dominates. The complete absence of $\eta<1$ for soils of clayey texture may be related to anion exclusion, as all these experiments were conducted with anionic tracers (see Fig. $4 \mathrm{~b}$ and discussion above). This is a counter-intuitive finding, and indeed we observed early tracer arrivals in the clay soils. However, in these soils the tailing of the BTC was also very strong, which leads to later average arrival times and larger $\eta$. It is worth noting that the absence of $\eta<1$ for clay soils may also be related to an artifact from the MIM transfer-function, as the tail of BTCs is to some extent extrapolated. Small $\eta$ occurs exclusively in loamy soils, which are characterized by a broader particle (and thus pore) size distribution than soils from other texture classes. As a broader pore size spectrum should enhance heterogeneous transport in the soil matrix, it is possible that, in addition to anion exclusion, $\eta$ reflects heterogeneous transport in the matrix rather than macropore flow.

Finally, we also investigated the relationships of the BTC shape-measures $\lambda_{\text {app }}$ and $p_{0.05}$ with land use and soil management practices. Figure 10a and $\mathrm{b}$ illustrate that the 585 undisturbed soil samples exhibited a median apparent dispersivity of $6.72 \mathrm{~cm}$ and a median normalized $5 \%$-arrival time of 0.3 , corresponding to steady state flow conditions with a median flux of $12.7 \mathrm{~cm} \mathrm{~d}^{-1}$ and a median travel distance of $20 \mathrm{~cm}$. Much smaller $p_{0.05}$ values were only found for samples from arable sites with reduced tillage and grass leys (Fig. 10a). However, the number of samples for these land use classes was very small, while Fig. 10b reveals that the experiments were conducted on relatively short columns and large water fluxes, both of which promote low $p_{0.05}$. Similarly, the experimental conditions were also not representative for the bulk of the experiments on undisturbed samples for the "forest" sites. For these samples, the experimental conditions promoted larger $p_{0.05}$ values (Fig. 10b). Figure 10a and $\mathrm{b}$ show that sieved and repacked soil samples resulted in clearly larger $p_{0.05}$ values than samples of undisturbed soil, even though the experimental conditions favoured small values. A lack of preferential transport for the disturbed samples is consistent with the destruction of natural well-connected pore structures by sieving. This furthermore 
a)
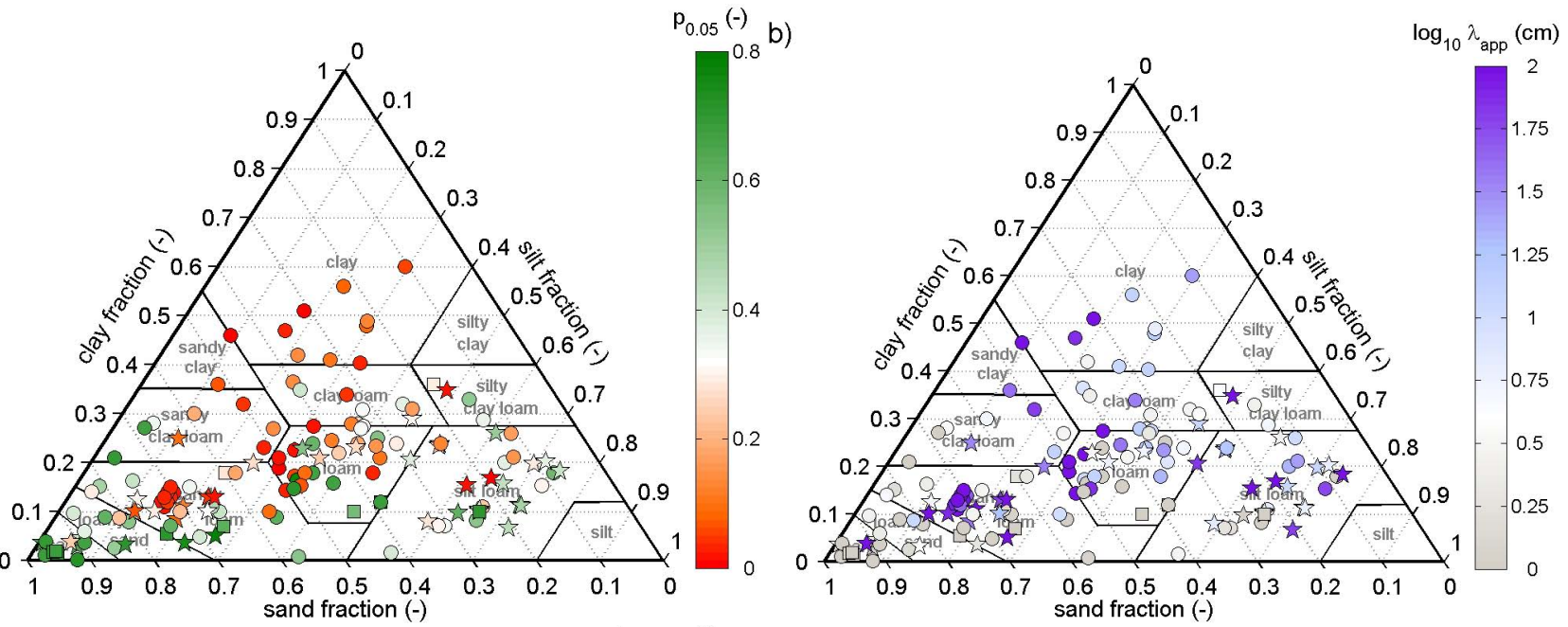

c)

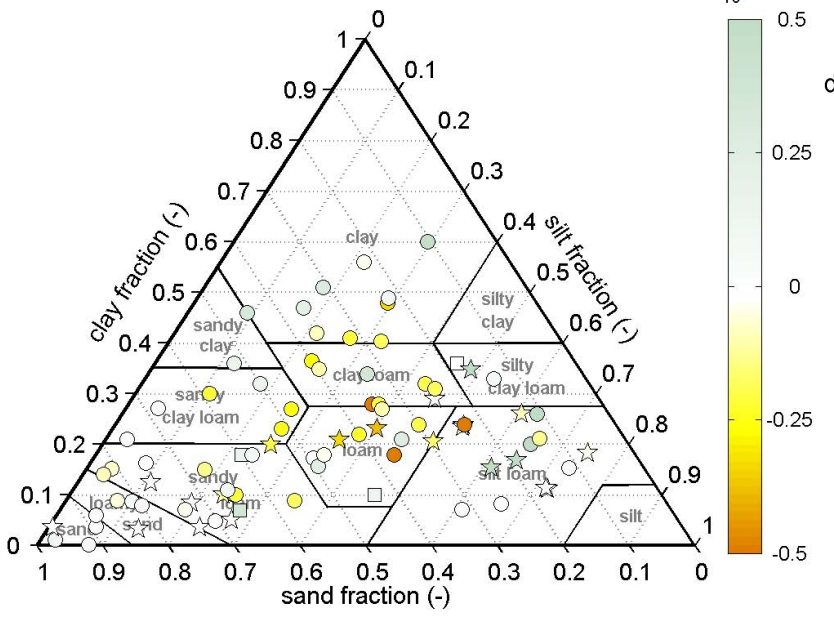

d)

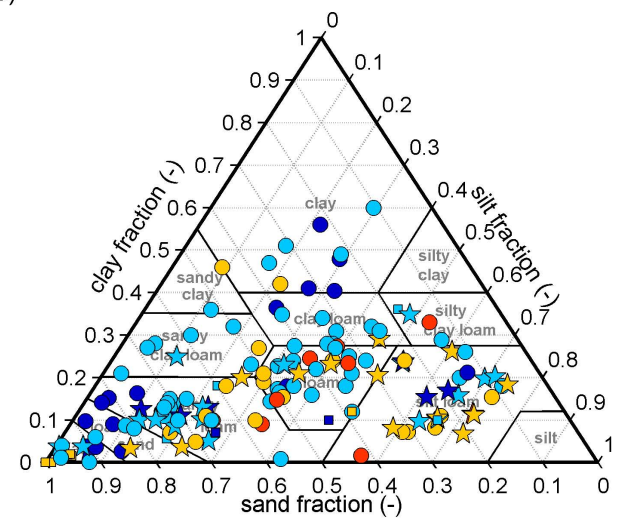

$\mathrm{q} \geq 120 \mathrm{~cm} \mathrm{~d}^{-1}$ $\square 120>\mathrm{q} \geq 12 \mathrm{~cm} \mathrm{~d}^{-1}$ $\square 12>\mathrm{q} \geq 1.2 \mathrm{~cm} \mathrm{~d}^{-1}$ $1.2>\mathrm{q} \mathrm{cm} \mathrm{d}^{-1}$ undisturbed, 1 horizon t3 undisturbed, 2 or more hor - sieved and repacked

Fig. 9. The (a) normalized $5 \%$-arrival time, $p_{0.05}$; (b) apparent dispersivity, $\lambda_{\text {app }}$; (c) the piston-flow to transport velocity ratio, $\eta$; and (d) the water flux classes corresponding to the considered BTC experiments.

underlines the importance of conducting leaching studies on undisturbed samples (see also Elrick and French, 1966; Cassel et al., 1974; McMahon and Thomas, 1974). Moreover, no sign of preferential transport was found for the BTCs collected from artificial porous media like clean sand or glass beads. They exhibited extremely large $p_{0.05}$ and extremely small $\lambda_{\text {app }}$, although the experimental conditions should have acted in the opposite direction. Of the natural soils, only the two samples from heathland sites consisting almost of pure sand (Seuntjens et al., 2001) show similar features (Fig. 10a). We conclude that, with a few exceptions, a complete absence of preferential characteristics in solute transport is only observed in artificial homogeneous porous media. Apart from this, our data do not show any clear relationship between land use and degree of preferential transport and solute dispersion. However, such relationships cannot be ruled out, since in our dataset they may have been obscured by a lack of comparable experimental conditions.

\section{Conclusions}

We investigated the controls on inert solute transport based on 733 breakthrough curve experiments collected from the peer-reviewed literature, mostly conducted on undisturbed soil columns. We focused especially on four breakthrough curve shape-measures: namely the normalized $5 \%$-arrival time, the holdback factor, the apparent longitudinal dispersivity and the ratio of piston-flow and average transport velocities. The normalized 5\%-arrival time, the apparent dispersivity and the holdback factor were strongly correlated, while only weak correlations were found between these shape-measures and the piston-flow to transport velocity ratio, suggesting that the latter contains complementary information on solute transport. In particular, our results suggest that the piston-flow to transport velocity ratio is more strongly related to exclusion or retardation of the applied tracer and preferential transport in the soil matrix, rather than to the degree of preferential solute transport in macropores. 


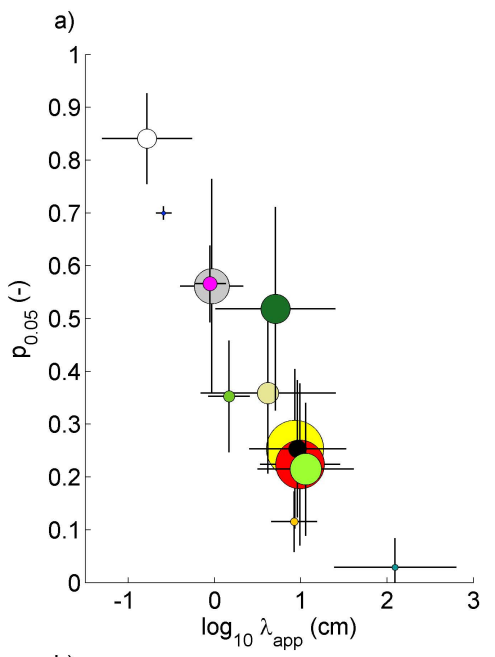

clean sand / glass beads repacked soil arable (all)

arable (unspec. tillage)

arable (conv. tillage)

arable (reduced tillage)

arable (no tillage)

forest

managed grassland

natural grassland

orchard

grass ley

heathland

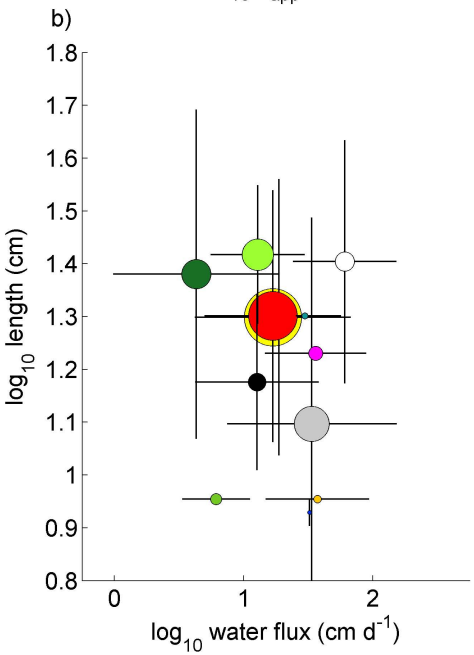

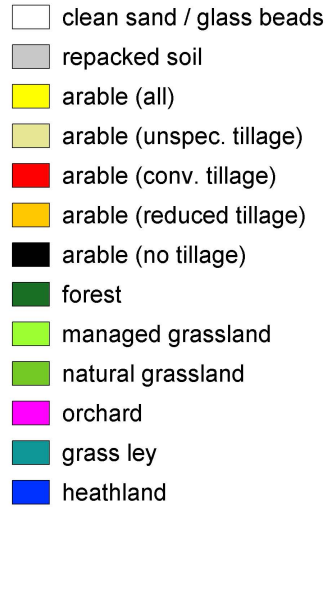

Fig. 10. (a) Comparison of the apparent dispersivity, $\lambda_{\text {app }}$, and normalized $5 \%$-arrival time, $p_{0.05}$, with the respective land use; (b) comparison of the water flux, $q$, and column length, $L$, with the respective land use. The center of each circle depicts the respective median value, and the error bounds indicate the corresponding interquartile range. The size of each circle corresponds to the number of samples within each land use class.

Our results confirm the findings of previous studies that the apparent longitudinal dispersivity is positively correlated with the travel distance of the tracer. We found that this relationship is refined if the normalized $5 \%$ tracer arrival time is also taken into account as a measure of the degree of preferential solute transport. In particular, we found that the degree of preferential solute transport increases with apparent dispersivity and decreases with travel distance. A similar relationship was found between the apparent dispersivity and the lateral observation scale. However, the effects of travel distance and lateral observation scale on these two measures are difficult to separate, as travel distance and breakthrough plane cross-sectional area were positively correlated.
The strength of preferential transport increased at larger flow rates and water saturations, which suggests that macropore flow was a dominant cause of non-equilibrium conditions for the experiments in our database. Nevertheless, our data show that heterogeneous flow in the soil matrix also occasionally leads to strong preferential transport characteristics, especially in loamy soils. It should also be noted here that most of the studies included in the database were conducted under relatively high intensity and steady-state irrigation boundary conditions and saturated or near-saturated initial conditions. Therefore, the general relevance of transport processes that are triggered under different initial and/or boundary conditions cannot be investigated with our database. Examples are unstable finger flow (Scheidegger, 1960; Raats, 1973; Hendrickx et al., 1993) and preferential transport due to soil hydrophobicity (Thomas et al., 1973; Ritsema and Dekker, 1996) or air-entrapment (Debacker, 1967; Sněhota et al., 2008). These flow and transport phenomena have been frequently investigated, but mostly with the aid of dye tracers and only occasionally by means of BTC experiments. The lack of appropriate studies to quantify the importance of these preferential transport processes as compared to the BTC experiments investigated here should be addressed in the future.

Preferential solute transport was shown to depend on soil texture in a threshold-like manner: moderate to strong preferential transport was only found in soils with a texture consisting of more than 8 to $9 \%$ clay. As expected, columns filled with glass beads, clean sands, or sieved soil exhibited no preferential transport. No clear effect of land use on the pattern of solute transport could be discerned. However, we suspect that the dataset was too small and also too strongly influenced by cross-correlations with soil type and experimental conditions to allow any firm conclusions to be drawn on this.

The database opens up the possibility to develop pedotransfer functions for solute transport properties in soil. Whilst they are generally encouraging, the results of the initial analyses presented in this paper suggest that this will be a challenging task. In particular, it will be critically important to distinguish the effects of experimental conditions (column dimensions, initial and boundary conditions) from the effects of soil and site characteristics. Some initial attempts in this direction are underway.

Edited by: M. Weiler 


\section{References}

Akhtar, M. S., Richards, B. K., Medrano, P. A., deGroot, M., and Steenhuis, T. S.: Dissolved phosphorus from undisturbed soil cores: Related to adsorption strength, flow rate, or soil structure? Soil Sci. Soc. Am. J., 67, 458-470, 2003.

Anamosa, P. R., Nkedi-Kizza, P., Blue, W. G., and Sartain, J. B.: Water-movement through an aggregated, gravelly oxisol from Cameroon, Geoderma, 46, 263-281, 1990.

Bedmar, F., Costa, J. L., and Gimenez, D.: Column tracer studies in surface and subsurface horizons of two typic argiudolls, Soil Sci., 173, 237-247, 2008.

Beven, K. J., Henderson, D. E., and Reeves, A. D.: Dispersion parameters for undisturbed partially saturated soil, J. Hydrol., 143, 19-43, 1993.

Bromly, M. and Hinz, C.: Non-Fickian transport in homogeneous unsaturated repacked sand, Water Resour. Res., 40, W07402, doi:10.1029/2003WR002579, 2004.

Bromly, M., Hinz, C., and Aylmore, L. A. G.: Relation of dispersivity to properties of homogeneous saturated repacked soil columns, Eur. J. Soil Sci., 58, 293-301, 2007.

Candela, L., Álvarez-Benedí, J., Condesso de Melo, M. T., and Rao, P. S. C.: Laboratory studies on glyphosate transport in soils of the Maresme area near Barcelona, Spain: Transport model parameter estimation, Geoderma, 140, 8-16, 2007.

Cassel, D. K., Krueger, T. H., Schroer, F. W., and Norum, E. B.: Solute movement through disturbed and undisturbed soil cores, Soil Sci. Soc. Am. J., 38, 36-40, 1974.

Coats, K. H. and Smith, B. D.: Dead-end pore volume and dispersion in porous media, Soc. Petrol. Eng. J., 4, 73-84, 1964.

Comegna, V., Coppola, A., and Sommella, A: Nonreactive solute transport in variously structured soil materials as determined by laboratory-based time domain reflectometry (TDR), Geoderma, 92, 167-184, 1999.

Comegna, V., Coppola, A., and Sommella, A.: Effectiveness of equilibrium and physical non-equilibrium approaches for interpreting solute transport through undisturbed soil columns, J. Contam. Hydrol., 50, 121-138, 2001.

de Smedt, F. and Wierenga, P. J.: Solute transfer through columns of glass beads, Water Resour. Res., 20, 225-232, 1984.

Danckwerts, P. V.: Continuous flow systems - distribution of residence times, Chem. Eng. Sci., 2, 1-13, 1953.

Debacker, L. W.: Measurement of entrapped gas in study of unsaturated flow phenomena, Water Resour. Res., 3, 245-249, 1967.

Dousset, S., Chauvin, C., Durlet, P., and Thevenot, M.: Transfer of hexazinone and glyphosate through undisturbed soil columns in soils under Christmas tree cultivation, Chemosphere, 57, 265272, 2004.

Dufey, J. E., Sheta, T. H., Gobran, G. R., and Laudelout, H.: Dispersion of chloride, sodium, and calcium-ions in soils as affected by exchangeable sodium, Soil Sci. Soc. Am. J., 46, 47-50, 1982.

Dyson, J. S. and White, R. E.: A comparison of the convectiondispersion equation and transfer function model for predicting chloride leaching through an undisturbed, structured clay soil, Eur. J. Soil Sci., 38, 157-172, 1987.

Dyson, J. S. and White, R. E.: The effect of irrigation rate on solute transport in soil during steady state water-flow, J. Hydrol., 107, 19-29, 1989.

Elrick, D. E. and French, L. K.: Miscible displacement patterns of disturbed and undisturbed soil cores, Soil Sci. Soc. Am. Pro., 30,
153-156, 1966.

Ersahin, S., Papendick, R. I., Smith, J. L., Keller, C. K., and Manoranjan, V. S.: Macropore transport of bromide as influenced by soil structure differences, Geoderma, 108, 207-223, 2002.

Flühler, H., Durner, W., and Flury, M.: Lateral solute mixing processes - A key for understanding field-scale transport of water and solutes, Geoderma, 70, 165-183, 1996.

Gaber, H. M., Inskeep, W. P., Comfort, S. D., and Wraith, J. M.: Nonequilibrium transport of atrazine through large intact soil cores, Soil Sci. Soc. Am. J., 59, 60-67, 1995.

Garré, S., Koestel, J., Günther, T., Javaux, M., Vanderborght, J., and Vereecken, H.: Comparison of heterogeneous transport processes observed with electrical resistivity tomography in two toils, Vadose Zone J., 9, 336-349, 2010.

Gaston, L. A. and Locke, M. A.: Bentazon mobility through intact, unsaturated columns of conventional and no-till Dundee soil, J. Environ. Qual., 25, 1350-1356, 1996.

Gaston, L. A. and Locke, M. A.: Acifluorfen sorption, degradation, and mobility in a Mississippi delta soil, Soil Sci. Soc. Am. J., 64, 112-121, 2000.

Gaston, L. A., Locke, M., McDonald, J., Dodla, S., Liao, L., Putnam, L., and Udeigwe, T.: Effects of tillage on norflurazon sorption, degradation and mobility in a mississippi delta soil, Soil Sci., 172, 534-545, 2007.

Gelhar, L. W., Welty, C., and Rehfeldt, K. R.: A critical-review of data on field-scale dispersion in aquifers, Water Resour. Res., 28, 1955-1974, 1992.

Goncalves, M. C., Leij, F. J., and Schaap, M. G.: Pedotransfer functions for solute transport parameters of Portuguese soils, Eur. J. Soil Sci., 52, 563-574, 2001.

Green, J. D., Horton, R., and Baker, J. L.: Crop residue effects on leaching of surface-applied chemicals, J. Environ. Qual., 24, 343-351, 1995.

Griffioen, J. W., Barry, D. A., and Parlange, J. Y.: Interpretation of two-region model parameters, Water Resour. Res., 34, 373-384, 1998.

Gwo, J. P., Jardine, P. M., Wilson, G. V., and Yeh, G. T.: A multiplepore-region concept to modeling mass-transfer in subsurface media, J. Hydrol., 164, 217-237, 1995.

Haws, N. W., Das, B. S., and Rao, P. S. C.: Dual-domain solute transfer and transport processes: evaluation in batch and transport experiments, J. Contam. Hydrol., 75, 257-280, 2004.

Hendrickx, J. M. H., Dekker, L. W., and Boersma, O. H.: Unstable wetting fronts in water-repellent field soils, J. Environ. Qual., 22, 109-118, 1993.

Hendrickx, J. M. H. and Flury, M.: Uniform and preferential flow mechanisms in the vadose zone, in: Conceptual Models of Flow and Transport in the Fractured Vadose Zone, National Academy Press, Washington D.C., 149-187, 2001.

Helmke, M. F., Simpkins, W. W., and Horton, R.: Fracturecontrolled nitrate and atrazine transport in four Iowa till units, J. Environ. Qual., 34, 227-236, 2005.

Horn, R., Taubner, H., Wuttke, M., and Baumgartl, T.: Soil physical properties related to soil structure, Soil Tillage Res., 30, 187216, 1994.

Hunt, A. G. and Skinner, T. E.: Predicting Dispersion in Porous Media, Complexity, 16, 43-55, 2010.

Jacobsen, O. H., Leij, F. J., and van Genuchten, M. T.: Parameter determination for chloride and tritium transport in undisturbed 
lysimeters during steady state flow, Nord. Hydrol., 23, 89-104, 1992.

Javaux, M. and Vanclooster, M.: Scale- and rate-dependent solute transport within an unsaturated sandy monolith, Soil Sci. Soc. Am. J., 67, 1334-1343, 2003.

Jensen, K. H., Destouni, G., and Sassner, M.: Advection-dispersion analysis of solute transport in undisturbed soil monoliths, Ground Water, 34, 1090-1097, 1996.

Jensen, M. B., Hansen, H. C. B., Hansen, S., Jorgensen, P. R., Magid, J., and Nielsen, N. E.: Phosphate and tritium transport through undisturbed subsoil as affected by ionic strength, J. Environ. Qual., 27, 139-145, 1998.

Jorgensen, P. R., Helstrup, T., Urup, J., and Seifert, D.: Modeling of non-reactive solute transport in fractured clayey till during variable flow rate and time, J. Contam. Hydrol., 68, 193-216, 2004.

Jury, W. A. and Flühler, H.: Transport of chemicals through soil - mechanisms, models, and field applications, Adv. Agron., 47, 141-201, 1992

Jury, W. A. and Roth, K.: Transfer functions and solute movement through soil: theory and applications, Birkhauser Verlag AG, Basel Switzerland, 226 pp., 1990.

Kamra, S. K., Lennartz, B., van Genuchten, M. T., and Widmoser, P.: Evaluating non-equilibrium solute transport in small soil columns, J. Contam. Hydrol., 48, 189-212, 2001.

Kasteel, R., Vogel, H. J., and Roth, K.: From local hydraulic properties to effective transport in soil, Eur. J. Soil Sci., 51, 81-91, 2000.

Kim, S. B., On, H. S., Kim, D. J., Jury, W. A., and Wang, Z.: Determination of bromacil transport as a function of water and carbon content in soils, J. Environ. Sci. Heal. B, 42, 529-537, 2007.

Kjaergaard, C., Poulsen, T. G., Moldrup, P., and de Jonge, L. W.: Colloid mobilization and transport in undisturbed soil columns: 1. Pore structure characterization and tritium transport, Vadose Zone J., 3, 413-423, 2004.

Knudby, C. and Carrera, J.: On the relationship between indicators of geostatistical, flow and transport connectivity, Adv. Water Resour., 28, 405-421, 2005.

Koestel, J. K., Vanderborght, J., Javaux, M., Kemna, A., Binley, A., and Vereecken, H.: Noninvasive 3-D transport characterization in a sandy soil using ERT: 1. Investigating the validity of ERTderived transport parameters, Vadose Zone J., 8, 711-722, 2009a.

Koestel, J. K., Vanderborght, J., Javaux, M., Kemna, A., Binley, A., and Vereecken, H.: Noninvasive 3-D transport characterization in a sandy soil using ERT: 2. Transport process inference, Vadose Zone J., 8, 723-734, 2009b.

Koestel, J. K., Moeys, J., and Jarvis, N. J.: Evaluation of nonparametric shape-measures for solute breakthrough curves, Vadose Zone J., 10, 1261-1275, 2011.

Krupp, H. K. and Elrick, D. E.: Miscible displacement in an unsaturated glass bead medium, Water Resour. Res., 4, 809-815, 1968.

Langner, H. W., Gaber, H. M., Wraith, J. M., Huwe, B., and Inskeep, W. P.: Preferential flow through intact soil cores: Effects of matric head, Soil Sci. Soc. Am. J., 63, 1591-1598, 1999.

Lee, J., Horton, R., and Jaynes, D. B.: A time domain reflectometry method to measure immobile water content and mass exchange coefficient, Soil Sci. Soc. Am. J., 64, 1911-1917, 2000.

Lee, J., Horton, R., Noborio, K., and Jaynes, D. B.: Characterization of preferential flow in undisturbed, structured soil columns using a vertical TDR probe, J. Contam. Hydrol., 51, 131-144, 2001.

Lennartz, B., Haria, A. H., and Johnson, A. C.: Flow regime effects on reactive and non-reactive solute transport, Soil Sediment Contam., 17, 29-40, 2008.

Luo, L., Lin, H., and Schmidt, J.: Quantitative relationships between soil macropore characteristics and preferential flow and transport, Soil Sci. Soc. Am. J., 74, 1929-1937, 2010.

Maraqa, M. A., Wallace, R. B., and Voice, T. C.: Effects of degree of water saturation on dispersivity and immobile water in sandy soil columns, J. Contam. Hydrol., 25, 199-218, 1997.

Mayes, M. A., Jardine, P. M., Mehlhorn, T. L., Bjornstad, B. N., Ladd, T., and Zachara, J. M.: Transport of multiple tracers in variably saturated humid region structured soils and semi-arid region laminated sediments, J. Hydrol., 275, 141-161, 2003.

McIntosh, J., McDonnell, J. J., and Peters, N. E.: Tracer and hydrometric study of preferential flow in large undisturbed soil cores from the Georgia Piedmont, USA, Hydrol. Process., 13, 139$155,1999$.

McMahon, M. A. and Thomas, G. W.: Chloride and tritiated water flow in disturbed and undisturbed soil cores, Soil Sci. Soc. Am. J., 38, 727-732, 1974.

Montoya, J. C., Costa, J. L., Liedl, R., Bedmar, F., and Daniel, P.: Effects of soil type and tillage practice on atrazine transport through intact soil cores, Geoderma, 137, 161-173, 2006.

Mooney, S. J. and Morris, C.: A morphological approach to understanding preferential flow using image analysis with dye tracers and X-ray Computed Tomography, Catena, 73, 204-211, 2008.

Nemes, A., Wösten, J. H. M., Lilly, A., and Voshaar, J. H. O.: Evaluation of different procedures to interpolate particle-size distributions to achieve compatibility within soil databases, Geoderma, 90, 187-202, 1999.

Neuman, S. P.: Universal scaling of hydraulic conductivities and dispersivities in geologic media, Water Resour. Res., 26, 17491758, 1990.

Nkedi-Kizza, P., Biggar, J. W., van Genuchten, M. T., Wierenga, P. J., Selim, H. M., Davidson, J. M., and Nielsen, D. R.: Modeling tritium and chloride-36 transport through an aggregated oxisol, Water Resour. Res., 19, 691-700, 1983.

Öhrström, P., Persson, M., Albergel, J., Zante, P., Nasri, S., Berndtsson, R., and Olsson, J.: Field-scale variation of preferential flow as indicated from dye coverage, J. Hydrol., 257, 164-173, 2002.

Oliver, Y. M. and Smettem, K. R. J.: Parameterisation of physically based solute transport models in sandy soils, Aust. J. Soil Res. 41, 771-788, 2003.

Pang, L., McLeod, M., Aislabie, J., Simunek, J., Close, M., and Hector, R.: Modeling transport of microbes in ten undisturbed soils under effluent irrigation, Vadose Zone J., 7, 97-111, 2008.

Perfect, E., Sukop, M. C., and Haszler, G. R.: Prediction of dispersivity for undisturbed soil columns from water retention parameters, Soil Sci. Soc. Am. J., 66, 696-701, 2002.

Pot, V., Simunek, J., Benoit, P., Coquet, Y., Yra, A., and MartinezCordon, M. J.: Impact of rainfall intensity on the transport of two herbicides in undisturbed grassed filter strip soil cores, J. Contam. Hydrol., 81, 63-88, 2005.

Poulsen, T. G., Moldrup, P., de Jonge, L. W., and Komatsu, T.: Colloid and bromide transport in undisturbed soil columns: Application of two-region model, Vadose Zone J., 5, 649-656, 2006.

Prado, B., Duwig, C., Escudey, M., and Esteves, M.: Nitrate sorption in a mexican allophanic andisol using intact and packed 
columns, Commun. Soil Sci. Plan., 37, 2911-2925, 2006.

Prado, B., Duwig, C., Marquez, J., Delmas, P., Morales, P., James, J., and Etchevers, J.: Image processing-based study of soil porosity and its effect on water movement through andosol intact columns, Agric. Water Manage., 96, 1377-1386, 2009.

Quisenberry, V. L., Smith, B. R., Phillips, R. E., Scott, H. D., and Nortcliff, S.: A soil classification-system for describing water and chemical transport, Soil Sci., 156, 306-315, 1993

Raats, P. A. C.: Unstable wetting fronts in uniform and nonuniform soils, Soil Sci. Soc. Am. J., 37, 681-685, 1973.

Raturi, S., Hill, R. L., and Carroll, M. J.: Modeling dicamba sorption and transport through zoysiagrass thatch and soil, Soil Sediment Contam., 10, 227-247, 2001.

Ren, G. L., Izadi, B., King, B., and Dowding, E.: Preferential transport of bromide in undisturbed cores under different irrigation methods, Soil Sci., 161, 214-225, 1996.

Reungsang, A., Moorman, T. B., and Kanwar, R. S.: Transport and fate of atrazine in midwestern riparian buffer strips, J. Am. Water Resour. Assoc., 37, 1681-1692, 2001.

Ritsema, C. J. and Dekker, L. W.: Water repellency and its role in forming preferred flow paths in soils, Aust. J. Soil Res., 34, 475487, 1996

Rose, D. A.: Some aspects of hydrodynamic dispersion of solutes in porous materials, J. Soil Sci., 24, 285-295, 1973.

Rose, D. A.: Hydrodynamic dispersion in porous materials, Soil Sci., 123, 277-283, 1977.

Rose, D. A., Abbas, F., and Adey, M. A.: The effect of surfacesolute interactions on the transport of solutes through porous materials, Eur. J. Soil Sci., 60, 398-411, 2009.

Scheidegger, A. E.: Growth of instabilities on displacement fronts in porous media, Phys. Fluids, 3, 94-104, 1960.

Scherr, F.: Sorption, degradation and transport of estrogens and estrogen sulphates in agricultural soils, Ph. D. thesis, Lincoln University, Lincoln, New Zealand, 2009.

Schoen, R., Gaudet, J. P., and Elrick, D. E.: Modelling of solute transport in a large undisturbed lysimeter, during steady-state water flux, J. Hydrol., 215, 82-93, 1999.

Schulin, R., Wierenga, P. J., Flühler, H., and Leuenberger, J.: Solute transport through a stony soil, Soil Sci. Soc. Am. J., 51, 36-42, 1987.

Segal, E., Shouse, P., and Bradford, S. A.: Deterministic analysis and upscaling of bromide transport in a heterogeneous vadose zone, Vadose Zone J., 8, 601-610, 2009.

Selim, H. M. and Amacher, M. C.: A 2nd-order kinetic approach for modeling solute retention and transport in soils, Water Resour. Res., 24, 2061-2075, 1988.

Seo, Y. and Lee, J.: Characterizing preferential flow of nitrate and phosphate in soil using time domain reflectometry, Soil Sci., 170, 47-54, 2005.

Seuntjens, P., Tirez, K., Simunek, J., van Genuchten, M. T., Cornelis, C., and Geuzens, P.: Aging effects on cadmium transport in undisturbed contaminated sandy soil columns, J. Environ. Qual., 30, 1040-1050, 2001.

Seyfried, M. S. and Rao, P. S. C.: Solute transport in undisturbed columns of an aggregated tropical soil - preferential flow effects, Soil Sci. Soc. Am. J., 51, 1434-1444, 1987.

Shaw, J. N., West, L. T., Radcliffe, D. E., and Bosch, D. D.: Preferential flow and pedotransfer functions for transport properties in sandy kandiudults, Soil Sci. Soc. Am. J., 64, 670-678, 2000.
Shirazi, M. A., Boersma, L., and Johnson, C. B.: Particle-size distributions: Comparing texture systems, adding rock, and predicting soil properties, Soil Sci. Soc. Am. J., 65, 300-310, 2001.

Singh, P. and Kanwar, R. S.: Preferential solute transport through macropores in large undisturbed saturated soil columns, J. Environ. Qual., 20, 295-300, 1991.

Skaggs, T. H., Kabala, Z. J., and Jury, W. A.: Deconvolution of a nonparametric transfer function for solute transport in soils, J. Hydrol., 207, 170-178, 1998.

Smettem, K. R. J.: Soil-water residence time and solute uptake. 3: Mass-transfer under simulated winter rainfall conditions in undisturbed soil cores, J. Hydrol., 67, 235-248, 1984.

Smettem, K. R. J., Trudgill, S. T., and Pickles, A. M.: Nitrate loss in soil drainage waters in relation to by-passing flow and discharge on an arable site, J. Soil Sci., 34, 499-509, 1983.

Sněhota, M., Sobotkova, M., and Císlerová, M.: Impact of the entrapped air on water flow and solute transport in heterogeneous soil: Experimental setup, J. Hydrol. Hydromech., 56, 247-256, 2008.

Stagnitti, F., Allinson, G., Morita, M., Nishikawa, M., Ii, H., and Hirata, T.: Temporal moments analysis of preferential solute transport in soils, Environ. Model. Assess., 5, 229-236, 2000.

Thomas, G. W. and Swoboda, A. R.: Anion exclusion effects on chloride movement in soils, Soil Sci., 110, 163-166, 1970.

Thomas, G. W., Blevins, R. L., Phillips, R. E., and McMahon, M. A.: Effect of a killed sod mulch on nitrate movement and corn yield, Agron. J., 65, 736-739, 1973.

Toride, N., Leij, F. J., and van Genuchten, M. T.: The CXTFit code for estimating transport parameters from laboratory or field tracer experiments. Version 2.1. USDA Research Report. Riverside, CA, US Salinity Laboratory, USDA, 137, 1999.

Tyler, D. D. and Thomas, G. W.: Chloride movement in undisturbed soil columns, Soil Sci. Soc. Am. J., 45, 459-461, 1981.

Unold, M., Simunek, J., Kasteel, R., Groeneweg, J., and Vereecken, H.: Transport of manure-based applied sulfadiazine and its main transformation products in soil columns, Vadose Zone J., 8, 677689, 2009.

Valocchi, A. J.: Validity of the local equlibrium assumption for modeling sorbing solute transport through homogeneous soils, Water Resour. Res., 21, 808-820, 1985.

Vanderborght, J. and Vereecken, H.: Review of dispersivities for transport modeling in soils, Vadose Zone J., 6, 29-52, 2007.

Vanderborght, J., Vanclooster, M., Timmerman, A., Seuntjens, P., Mallants, D., Kim, D.-J., Jacques, D., Hubrechts, L., Gonzalez, C., Feyen, J., Diles, J., and Deckers, J.: Overview of inert tracer experiments in key Belgian soil types: relation between transport and soil morphological and hydraulic properties, Water Resour. Res., 37, 2873-2888, 2001.

Vanderborght, J., Gähwiller, P., and Flühler, H.: Identification of transport processes in soil cores using fluorescent tracers, Soil Sci. Soc. Am. J., 66, 774-787, 2002.

Vervoort, R. W., Radcliffe, D. E., and West, L. T.: Soil structure development and preferential solute flow, Water Resour. Res., 35, 913-928, 1999.

Vincent, A., Benoit, P., Pot, V., Madrigal, I., Delgado-Moreno, L., and Labat, C.: Impact of different land uses on the migration of two herbicides in a silt loam soil: unsaturated soil column displacement studies, Eur. J. Soil Sci., 58, 320-328, 2007. 
Vogeler, I., Horn, R., Wetzel, H., and Krümmelbein, J.: Tillage effects on soil strength and solute transport, Soil Till. Res., 88, 193-204, 2006.

Wilson, G. V., Yunsheng, L., Selim, H. M., Essington, M. E., and Tyler, D. D.: Tillage and cover crop effects on saturated and unsaturated transport of fluometuron, Soil Sci. Soc. Am. J., 62, 46$55,1998$.
Wösten, J. H. M., Pachepsky, Y. A., and Rawls, W. J.: Pedotransfer functions: bridging the gap between available basic soil data and missing soil hydraulic characteristics, J. Hydrol., 251, 123-150, 2001.

Zurmühl, T.: Capability of convection-dispersion transport models to predict transient water and solute movement in undisturbed soil columns, J. Contam. Hydrol., 30, 101-128, 1998. 